\title{
TMS, BOBİ FRS VE VUK/MSUGT'E GÖRE STOKLARIN KARŞILAŞTIRMALI OLARAK INCELENMESİ VE MUHASEBE UYGULAMALARI
}

\section{COMPARATIVE INVESTIGATION OF STOCK ACCORDING TO TAS, FRS FOR LMES AND TPL AND ACCOUNTING PRACTICES}

\author{
Hakk1 KIYMIK $^{1}$
}

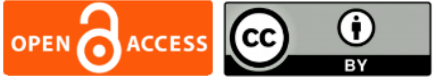

1. Dr. Öğr. Üyesi, Burdur Mehmet Akif Ersoy Üniversitesi, Bucak Zeliha Tolunay Uygulamal1 Teknoloji ve İșletmecilik Yüksekokulu, Muhasebe ve Finansal Yönetim Bölümü,

hkiymik@mehmetakif.edu.tr, https://orcid.org/0000-0002-4121-8060

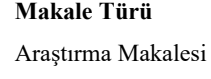

DOI
02.11 .2021

Article Type Research Article

Application Date 01.14 .2021

(1)

\section{Öz}

Bünyesinde bulundukları işletmelerin büyüklükleri ve faaliyet alanları ne olursa olsun stoklar, tüm işletmeler için önemli bir finansal tablo kalemini oluşturmaktadır. Yürürlükte olan finansal raporlama çerçevelerine göre stokların ölçümü ve muhasebeleştirilmesinde bir takım farklılık ve benzerlikler bulunmaktadır. Çalışmada, halen yürürlükte olan Vergi Usul Kanunu / Muhasebe Sistemi Uygulama Genel Tebliği, Türkiye Muhasebe Standartları ve Büyük ve Orta Boy İşletmeler İçin Finansal Raporlama Standartlarına göre stoklar, tanım ve kapsam, maliyetlerin belirlenmesi ve dönem sonu değerleme ilkeleri bakımından açıklanmış ve yürürlükteki düzenlemeler bakımından karşılaştırma yapılmıştır. Yapılan değerlendirme neticesinde, vade farkları, dönem sonu değerleme ve kapsamına göre maliyet hesaplama yöntemlerinin kullanımı açışından düzenlemeler arasında farklılıkların bulunduğu sonucuna ulaşılmıştır. Çalışmada, stoklara ilişkin muhasebeleştirme işlemleri, Kamu Gözetimi Muhasebe Denetim Standartları Kurumu tarafindan yayımlanan "Muhasebe Standartlarına Uygun Hesap Planı Taslağı" esas alınarak yapılmıştır.

Anahtar Kelimeler: Stok, Türkiye Muhasebe Standardı 2, Vergi Usul Kanunu.

\section{Abstract}

Regardless of size and field of activity of the businesses they are involved in, stocks constitute an important financial statement item for all businesses. There are some differences and similarities in measurement and accounting of stocks according to the financial reporting frameworks in force. In this study, according to Tax Procedure Law, Turkey Accounting Standards and Financial Reporting Standard For Large and Medium-Sized Entities, stocks were explained in terms of definitions and scope, regulations in force which is still in force on, determination of cost and year-end valuation principles, and comparisons were made in terms of current regulations. As a result of evaluation, it has been concluded that there are differences between regulations in terms of delay interests, year-end valuation and the use of cost calculation methods according to their scope. In study, the accounting transactions regarding the stocks were made on the basis of "Financial Reporting Standards Appropriate Account Plan Draft" published by the Public Oversight Accounting and Auditing Standards Authority.

Keywords: Anahtar Kelime, Anahtar Kelime2. 


\section{Research Problem}

\section{EXTENDED SUMMARY}

The purpose of this study is to examine accounting principles comparatively that are in force referring to measuring of inventory and recording Turkey Accounting Standards (TAS), Turkey Financial Reporting Standard For Large and Medium-Sized Entities (FRS for LMEs) and Turkey Tax Procedure Law (TPL).

\section{Research Questions}

The questions of the research are as follows: Is there a difference between financial reporting frameworks in terms of the definition and scope of stocks? Is there a difference between financial reporting frameworks in terms of measuring stocks? Is the tax legislation in line with FRS for LMEs and TAS regarding the measurement and recording of stocks?

\section{Literature Review}

In literature, there are studies that examine the provisions on stocks in TAS, FRS for LMEs and TPL from different perspectives. In these studies, the differences between TAS and TPL or TAS and FRS for LMEs were generally examined. In their study, Özulucan and Temel (2020) investigated the differences regarding stocks in terms of TAS 2 and TPL, and found that there were differences in terms of financing expenses, calculating inventory costs, valuation in inventory, and accounting for discounts. Arısoy and Tuğay (2019) revealed the differences between TAS 2 Stocks Standard, FRS for LMEs and TPL in terms of stocks. In the study, it was concluded that the main difference emerged in terms of cost methods and the normal cost method provided more realistic cost data than the full cost method. In the study conducted by Yalçın (2019), it was concluded that there were differences between the regulations in the determination of inventory costs and year-end valuation. In the study conducted by Kaya (2018), it was concluded that there are differences between standards in terms of TAS and FRS for LMEs, when the determination of inventory costs and the revenue regarding service is not reflected as income in the financial statements. In the study by Selvi and Ercan (2018) examining the differences between FRS for LMEs and TPL provisions regarding stocks, it is concluded that there are differences in terms of delay interest, cost calculation methods and valuation.

\section{Methodology}

In this study, provisions regarding stocks in TAS 2 Stocks Standard, FRS for LMEs Section 6 and TPL were analyzed comparatively through content analysis. In addition, accounting transactions were carried out using the draft chart of accounts created by Public Oversight Accounting and Auditing Standards Authority with the case study analysis method regarding the differences.

\section{Results and Conclusions}

According to results of this research, it was concluded that TAS and FRS for LMEs partially overlapped in terms of borrowing costs, while TPL was separated from the standard sets. According to standard sets, exchange differences arising in stock acquisitions should be recorded as period cost or 
income. According to the Tax Procedure Law, the part of the exchange differences until the date when the stocks are included in the operating assets must be included in the inventory cost. It is up to the enterprises to include the exchange differences that arise after the stocks are included in the operating assets, or to be recorded as period cost. Another important difference between TAS, FRS for LMEs and TPL arises in terms of cost elements included in the product cost. According to the TPL, the product cost is determined according to the full cost method. While the normal cost method has been adopted in calculating the product cost according to TAS 2, according to the FRS for LMEs, full cost or normal cost method can be used. In this regard, according to the TPL, all of the general production expenses are included in the cost of the product, while according to TAS and the normal cost method, the part corresponding to the idle capacity from the general production costs according to FRS for LMEs is not included in the product cost. According to the standard sets, while a share is not given to the cost of the product from the general management expenses, which do not contribute to bringing the stocks to their location and condition, according to the Tax Procedure Law, the share of the product cost from the general management expenses is left to the choice of the enterprises. while year-end valuation of inventories is made according to TAS and FRS for LMEs over the cost value and the lower of the net realizable value in each reporting period, it is made over the cost price according to the TPL. In case of an impairment according to the Tax Procedure Tax Law, the precedent value must be determined in order to be able to record the impairment as a cost. In transactions related to the differences between the standard sets and the Tax Procedure Law, the tax amount related to the difference that occurs in the event of a tax effect should also be recorded as a deferred tax asset or liability. In this respect, it is thought that studies for harmonization of TPL and standards will be beneficial in terms of eliminating such complexities. 


\section{GÍRIŞ}

Stoklar, özellikle üretim işletmeleri olmak üzere tüm işletme türleri açısından, esas faaliyetleri ile doğrudan ilişkili olması sebebiyle oldukça önemli bir varlık unsurudur. Stok maliyetlerinin doğru bir şekilde ölçülebilmesi, kayda alınması, finansal tablolarda gösterilmesi gibi birçok problemin çözüm bulması, etkin bir muhasebe sistemi ile mümkün olmaktadır. Önemli bir finansal tablo kalemini oluşturan stokların muhasebeleştirilmesi ve ölçümüne ilişkin ilkeler tüm işletme türleri açısından Muhasebe Sistemi Uygulama Genel Tebliği (MSUGT) / Vergi Usul Kanunu (VUK) ile düzenlenmiştir. Ayrıca kapsamına aldığı işletme türlerine göre Türkiye Muhasebe Standartları (TMS) ve bununla birlikte Büyük ve Orta Boy İşletmeler İçin Finansal Raporlama Standardı (BOBİ FRS) ile stokların ölçümüne ve muhasebeleştirilmesine ilişkin birtakım düzenlemeler yapılmıştır.

VUK'un 274, 275 ve 278. maddeleri ile stoklarla ilgili doğrudan bir düzenleme yapılmış olmakla birlikte farklı durumların ortaya çıkması halinde referans alınması gereken bazı maddeler de bulunmaktadır. Ülkemizde yürürlükte olan bir başka yasal düzenleme olan Muhasebe Sistemi Uygulama Genel Tebliğinde ise tebliğe ekli Tek Düzen Hesap Planında stoklar, 15.grupta sınıflandırılmıştır. Uluslararası Finansal Raporlama Standartlarına paralel olarak kamu yararını ilgilendiren kuruluşların (KAYIK) uymak zorunda oldukları TMS 2 Stoklar standardı 2006 yılından itibaren uygulanmak üzere 15.01.2005 tarihinde Resmi Gazetede yayımlanarak yürürlüğe girmiştir. Standartta, uyumlaştırma çalışmaları kapsamında farklı dönemlerde değişiklikler yapılmış ve son olarak KGK tarafından başlatılan revizyon projesi kapsamında mevcut standart 24.05.2018 tarihinde yürürlükten kaldırılarak yeniden kaleme alınan standart aynı tarihte yürürlüğe girmiştir. Stoklarla ilgili bir başka düzenleme ise 29.07.2017 tarihinde yayımlanan Büyük ve Orta Boy İşletmeler İçin Finansal Raporlama Standardıdır. Bağımsız denetime tabi olup TMS/TFRS uygulamayan işletmelerin uymak zorunda oldukları standardın 6. Bölümünde stoklara ilişkin düzenlemeler yapılmıştır.

Yürürlükte olan tüm bu düzenlemeler incelendiğinde, stokların ölçüm ve muhasebeleştirilmesi ile ilgili bir takım farklılık ve benzerliklerin bulunduğu anlaşılmaktadır. Bu farklılıklar genel olarak; değerleme, değer düşüklüğü, farklı maliyet yöntemlerinin kullanımı, alışlarda ortaya çıkan borçlanma maliyetlerinin kayda alınması konularında kendini göstermektedir. Çalışmada, stoklara ilişkin VUK/MSUGT, TMS ve BOBİ FRS'de yer alan muhasebe ilkeleri içerik analizi yöntemiyle karşılaştırmalı olarak incelenmiş ve KGK tarafindan yayımlanan taslak hesap planına göre örnekler üzerinden muhasebe kayıtları yapılarak çalışmanın uygulamaya 1şık tutması amaçlanmıştır.

\section{TANIM VE KAPSAM BAKIMINDAN KARŞILAŞTIRMA}

MSUGT'ye ekli TDHP'ye göre, “işletmenin satmak, üretimde kullanmak veya tüketmek amacıyla edindiği, ilk madde ve malzeme, yarı mamul, mamul, ticari mal, yan ürün, artık ve hurda gibi bir yıldan az bir sürede kullanılacak olan veya bir yıl içerisinde nakde çevrilebileceği düşünülen 
varlıklar" stok kapsamına girmektedir. Vergi Usul Kanunu'nda ise stoklar, emtia olarak ifade edilmiş olup imal edilen ve satın alınan olmak üzere ikiye ayrılmıştır. İmal edilen emtia, yarı mamul ve mamulü kapsamakta iken, satın alınan emtiadan ilk madde ve malzeme ile ticari mal anlaşılmaktadır (Selvi ve Ercan, 2018).

TMS 2'de tanımlar ve BOBİ FRS'de kapsam başlığı altında verilen stok tanımları ise örtüşmektedir. Standartlara göre stoklar; "olağan iş akışı içinde satılmak üzere elde tutulan, satılmak üzere üretilmekte olan veya üretim sürecinde veya hizmet sunumunda kullanılacak hammadde ve malzeme şeklinde bulunan varlıklardır”. TMS 2'de, stok tanımının yanı sıra stok kalemleri ayrıntılı bir şekilde belirtilmiştir. Tanıma paralel olarak standart "satın alınan ve tekrar satılmak üzere elde tutulan mallar, işletme tarafindan üretilmiş olan veya üretim sürecinde olan mallar ile üretim sürecinde kullanılmak üzere bekletilen hammadde ve malzemeleri" stok olarak nitelendirmektedir. Hem TMS 2, hem de BOBİ FRS "finansal araç niteliğindeki stoklar ile tarımsal faaliyet kapsamındaki canlı varlıklar ile hasat zamanındaki tarımsal ürünleri” ilgili oldukları standartların kapsamına almış, söz konusu varlıkları stoklarla ilgili standart kapsamının dışında bırakmıştır (Bobi FRS 6.2-3; TMS 2, md.8).

TMS 2'de ayrıca, tarım ve orman ürünlerinin, hasat sonrası tarımsal ürünlerin, madenlerin ve madeni ürünlerinin, ilgili sektördeki yerleşik uygulamalar ve/veya üretimin belirli aşamalarında net gerçekleşebilir değer üzerinden ölçülmesi halinde, bu kalemlere standardın ölçüm hükümlerinin uygulanmayacağı belirtilmiştir. Benzer şekilde başkaları veya kendi hesabına mal alıp satmak suretiyle alım satıma aracılık edenler tarafından edinilen stokların satış maliyetleri düşülmüş gerçeğe uygun değer üzerinden ölçülmesi halinde, bu tür stoklara standardın ölçüm hükümlerinin uygulanmaması gerektiği ifade edilmiştir (TMS 2, md.3).

\section{STOK MALIYETLERININ BELIRLENMESINE YÖNELIK KARŞILAŞTIRMA}

Stokların ölçümü konusunda standart setleri arasında herhangi bir farklılık bulunmamakta olup, "stokların maliyet değeri ile net gerçekleşebilir değerden düşük olanı ile ölçülmesi” gerektiği hüküm altına alınmıştır (Bobi FRS 6.4; TMS 2 md.9). Ancak TMS 2'ye ek olarak BOBİ FRS'de ayrıca "organize olmuş piyasalarda işlem gören stok niteliğindeki altın ve diğer kıymetli madenlerin ise raporlama dönemi sonlarında piyasa değerleri üzerinden değerlemeye tabi tutulması" gerektiği ifade edilmiştir (Bobi FRS 6.5).

Hem TMS hem de BOBİ FRS'ye göre net gerçekleşebilir değer, "olağan işletme faaliyetleri kapsamında tahmin edilen satış fiyatından, tahmini tamamlanma maliyetlerinin ve satışı gerçekleştirmek için gerekli olan tahmini maliyetlerin çıkarılmasıyla elde edilen tutarı" ifade etmektedir (Bobi FRS 6.4; TMS 2 md.7). 
Vergi Usul Kanununda ise stokların değerlemesinin maliyet bedeli üzerinden yapılmas1 gerektiği belirtilmektedir. Maliyet bedeli, "iktisadi bir klymetin iktisap edilmesi veyahut değerinin artırılması münasebetiyle yapılan ödemelerle bunlara müteferri bilumum giderlerin toplamın ifade etmektedir" (VUK, md.274). Ayrica VUK'un 275. maddesinde imal edilen mamul maliyetinin hangi unsurlardan oluşacağı da belirtilmiştir. Buna göre mamul maliyetine dahil edilecek unsurlar;

• Mamulün vücuda getirilmesinde sarf olunan iptidai ve ham maddelerin bedeli,

- Mamule isabet eden işçilik,

- Genel imal giderlerinden mamule düşen pay,

- Ambalajlama giderleri,

- İsteğe bağlı olarak genel yönetim giderlerinden mamule düşen paylardan oluşmaktadır.

TMS/BOBİ FRS ve VUK bakımından stok maliyetlerini oluşturan unsurlar, Tablo 1'de gösterilmiştir.

Tablo 1. Stok Maliyetlerini Oluşturan Unsurlar

\begin{tabular}{|c|c|c|}
\hline Maliyet Unsurları & TMS/BOBİ FRS & VUK \\
\hline $\begin{array}{l}\text { Satın Alma } \\
\text { Maliyetleri }\end{array}$ & $\begin{array}{l}\text { - Satın alma fiyatı, } \\
\text { - İthalat vergileri ve iade alınamayan } \\
\text { diğer vergiler, } \\
\text { - Nakliye, yükleme ve boşaltma } \\
\text { giderleri, } \\
\text { - Mamul, malzeme ve hizmetlerin } \\
\text { elde edilmesiyle doğrudan } \\
\text { ilişkilendirilebilen diğer maliyetler, } \\
\text { - Ticari iskontolar, indirimler (-) }\end{array}$ & $\begin{array}{l}\text { - Satın alma maliyeti, } \\
\text { - Satın alma giderleri }\end{array}$ \\
\hline $\begin{array}{l}\text { Dönüştürme } \\
\text { Maliyetleri }\end{array}$ & $\begin{array}{l}\text { - Direkt ilk madde ve malzeme } \\
\text { giderleri, } \\
\text { - Direkt işçilik giderleri, } \\
\text { - Sabit ve değişken genel üretim } \\
\text { giderlerinden mamule dağitılan tutar, }\end{array}$ & $\begin{array}{l}\text { - Direkt ilk madde ve malzeme gideri } \\
\text { - Direkt işçilik gideri } \\
\text { - Genel üretim giderlerinden mamule } \\
\text { isabet eden tutar } \\
\text { - Yönetim giderlerinden mamule } \\
\text { isabet eden tutar (isteğe bağl1) }\end{array}$ \\
\hline Diğer Maliyetler & $\begin{array}{l}\text { - Stokların mevcut konumuna ve } \\
\text { durumuna getirilmesi için katlanılan } \\
\text { maliyetler }\end{array}$ & \\
\hline
\end{tabular}

Tablo 1'de görüldüğ̈̈ üzere, stokların maliyetini oluşturan unsurlar açısından TMS 2, BOBİ FRS ve VUK arasında herhangi bir farklılık bulunmamaktadır. Tüm düzenlemelere göre stok maliyeti, tüm satın alma maliyetleri, dönüştürme maliyetleri ve stokların bulunduğu yere ve mevcut durumuna getirilmesi için katlanılan diğer maliyetlerden oluşmaktadır (Bobi FRS 6.6; TMS 2 md.10). Ancak standartlar bu unsurların nelerden oluştuğunu ayrıntılı bir şekilde açıklarken VUK'ta genel bir tanımlama yapıldığı görülmektedir. 


\subsection{Satın Alma Maliyetleri}

Stokların maliyetini belirleyen unsurlar her ne kadar TMS, BOBİ FRS ve VUK açısından uyumlu olsa da VUK'ta hangi unsurların satınalma maliyetine dahil edileceği konusunda bir kesinlik bulunmamaktadır. VUK'ta genel bir tanım yapılarak, satın alma dolayısıyla ödenen bedeller ile yine satın almayla ilgili tüm giderlerin maliyete dahil edilmesi gerektiği ifade edilmiştir (VUK, md.262). Ancak, TMS ve BOBİ FRS'de satın alma maliyetine dahil edilmesi gereken unsurlar ayrıntılı bir şekilde belirtilmiştir. Buna göre stokların satın alma maliyetleri (Bobi FRS 6.7; TMS 2 md.11);

- Satın alma fiyat1,

- İthalat vergileri ve iade alınamayan diğer vergiler

- Nakliye, yükleme-boşaltma ve mamul, malzeme ve hizmetlerin edinimiyle doğrudan ilişkilendirilebilen diğer maliyetlerden oluşmaktadır.

TMS ve BOBİ FRS hangi unsurların satın alma maliyetine dahil edilmesi gerektiğini belirtmekle kalmayıp, ticari iskontolar, indirimler ve diğer benzer kalemlerin satın alma maliyetinden düşülmesi gerektiğini de ifade etmiştir (BOBİ FRS 6.7; TMS 2 md.11).

Satın alma maliyetleri açısından her ne kadar tüm düzenlemeler birbiriyle uyumlu gibi gözükse de VUK'ta genel bir düzenleme yapılmış olması sebebiyle, TMS ve BOBİ FRS'nin vadeli veya kredili alımlar ile dövize dayalı alımlar noktasında VUK'tan ayrıştı̆̆ını söylemek mümkündür. Bu bakımdan çalışmanın bu kısmında satın alma, yükleme-boşaltma, nakliye ve sigorta gibi uygulamalar açısından farklılık arzetmeyen işlemlere yer verilmemiş olup yalnızca farklılığın olduğu iş ve işlemlere yer verilmiştir.

\subsubsection{Borçlanma Maliyetleri}

Stokların vadeli alımlarında, peşin fiyat ile vadeli alış fiyatı arasındaki vade farkı tutarının muhasebeleştirilmesi konusunda düzenlemeler arasında birtakım farklılıklar bulunmaktadır. TMS 2'ye göre "satın alma anlaşmasının etkin bir şekilde bir finansman bileşeni içermesi durumunda bu bileşen, normal kredi koşulları için geçerli olan satın alma fiyatı ile ödenen tutar arasındaki fark, finansman sağlanan dönem boyunca faiz gideri olarak finansal tablolara yansittlır” (TMS 2, md.18).

BOBİ FRS'ye göre ise vadenin bir yıldan az ya da çok olması durumuna göre bir farklılık söz konusudur. Standarda göre bir yıl veya daha kısa vadeli bir ödeme karşılığında alım gerçekleşmesi halinde vade farkı ayrıştırması söz konusu olmadan, ödenen veya ödenmesi beklenen nakit tutar üzerinden alım tutarının stok maliyetine dahil edilmesi gerekmektedir (Bobi FRS: 6.8). Ancak vadenin bir yıldan uzun olması halinde, vade farkının etkin faiz yöntemine göre ayrıştırılarak ilgili stokun peşin fiyat üzerinden ölçülmesi ve ortaya çıkan vade farkı tutarının faiz gideri olarak finansal tablolara alınması gerekmektedir (Arısoy ve Tuğay, 2019). 
VUK ve MSUGT'ye göre ise stokların vadeli alınması durumunda ortaya çıkan vade farkı, maliyet bedelinin bir unsuru olarak söz konusu stok maliyetine dahil edilmesi gerekmektedir. Bununla birlikte 02.03.1995 tarihli Resmi Gazetede yayımlanan 238 sira nolu VUK Genel Tebliği’ne göre işletmelerin finansman temini maksadıyla bankalardan veya benzeri kredi kurumlarından aldıkları krediler için ödedikleri faiz ve komisyon giderlerini doğrudan gider kaydedebilecekleri gibi diledikleri takdirde stok maliyetine de dâhil edebilme imkanı tanınmıştır. Burada dikkat edilmesi gereken husus, stok maliyetine dahil edilebilecek borçlanma maliyetinin ilgili tebliğde banka kredileri ile sınırlı tutulmuş olması ve varlığın aktife alınmasından sonra ortaya çıkmış olması şartıdır (Selvi ve Ercan, 2018).

BOBİ FRS ve TMS'ye göre stok edinimlerinde ortaya çıkan borçlanma maliyetlerinin muhasebeleştirilmesinde, satın almaya konu edilen varlığın niteliği de önemlidir. Standartlara göre varlığın, özellikli varlık niteliğine sahip olmaması halinde borçlanma maliyetlerinin muhasebeleştirme esasları Tablo 2'de gösterilmiştir.

Tablo 2. Özellikli Varlık Niteliğinde Olmayan Stoklarda Borçlanma Maliyetlerinin Muhasebeleştirilmesi

\begin{tabular}{llll} 
Vade & $\boldsymbol{V U K}$ & $\boldsymbol{T M S}$ & BOBI FRS \\
\hline Bir Y1ldan K1sa & Maliyet & Gider & Maliyet \\
\hline Bir Y1ldan Uzun & Maliyet & Gider & Gider
\end{tabular}

Tablo 2'de görüldüğü üzere, VUK'ta vadeli alımlarda vade farkı ayrıştırılmamakta iken özellikli varlık niteliğinde olmayan stok edinimlerinde; TMS 2'ye göre tüm vade farkları ayrıştırılmakta; BOBİ FRS'ye göre ise sadece bir yıldan uzun vadeli alımlarda vade farkı ayrıştırılmakta ve faiz gideri olarak muhasebeleştirilmektedir (Gençoğlu, 2017).

Örnek: Toptan ayakkabı alım-satımı yapan işletme 01.03.2020 tarihinde KDV Hariç peşin fiyatı 150.000 TL olan ürünleri 4 ay vadeli olarak 160.000 TL'ye senet karşıllı̆̆ satın almıştır. \% 8 KDV tutarı peşin ödenmiştir.

VUK ve BOBİ FRS'ye göre yapılması gereken kayıt;

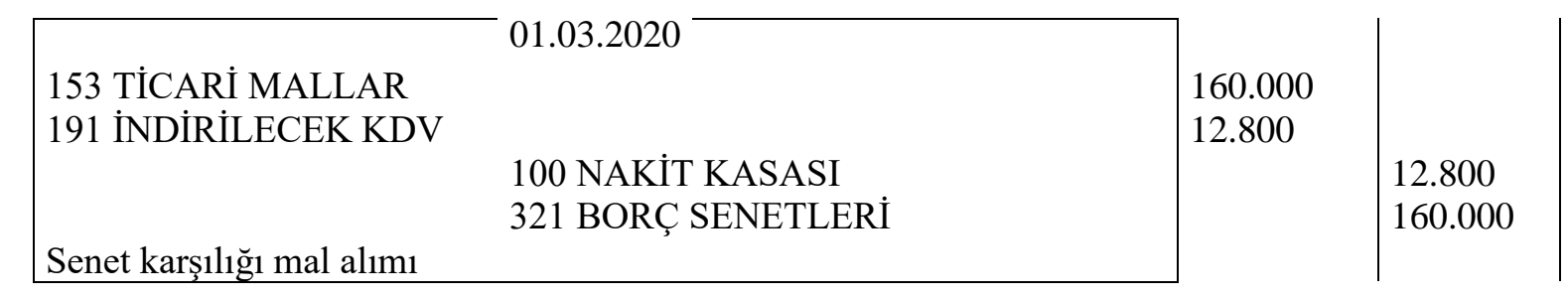

Daha önce de belirtildiği gibi VUK açısından alım esnasında ortaya çıkan vade farkının vade süresi ne olursa olun maliyete dahil edilmesi gerekmektedir. BOBİ FRS'ye göre ise bir yıldan kısa vadeli alımlarda ortaya çıkan vade farkının da benzer bir şekilde ilgili stok maliyetine ilave edilmesi gerekmektedir. Bu aşamada TMS, diğer iki uygulamadan farklılaşmakta olup, işlemin aşağıdaki gibi kaydedilmesi gerekmektedir; 


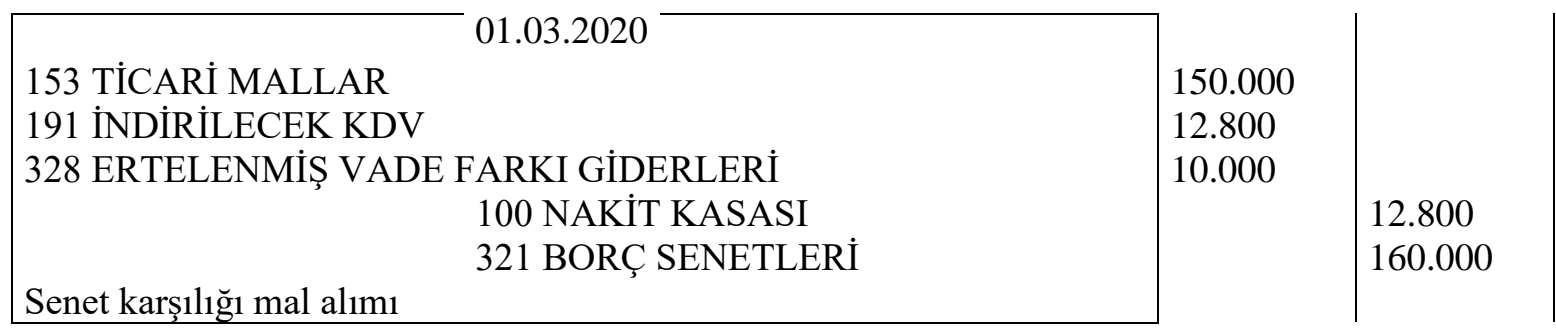

TMS 2’ye göre vade süresine bakılmaksızın özellikli varlık dışındaki varlık ediniminde ortaya çıkan vade farkının ilgili dönem gideri olarak kaydedilmesi gerekmektedir. Bu durumda peşin fiyat ile vadeli fiyat arasındaki tutarın taslak hesap planında öngörülen ve pasifi düzenleyici bir hesap olan "328 Ertelenmiş Vade Farkı Giderleri Hesabına" alınması gerekmektedir. Buna ilave olarak söz konusu vade farkı tutarının ilgili döneme ait olan kısmının etkin faiz yöntemine göre cari dönem giderine dahil edilmesi gerekmektedir. Bunun için öncelikle etkin faiz oranının hesaplanması gerekmekte olup faiz oranı aşağıdaki gibi hesaplanabilir (Özbirecikli vd., 2017);

Bugünkü Değer= $\frac{A}{(1+n)^{(t)}}$

Formülde n, etkin faiz oranını; $t$ ise vadeyi ifade etmektedir. Buna göre;

$$
\begin{aligned}
& 150.000=\frac{160.000}{(1+n)^{122 / 365}} \\
& (1+n)^{122 / 365}=160.000 / 150.000 \\
& 1+n=\sqrt[123]{1,066667^{365}} \\
& n=1,212987-1 \\
& n=0,212987
\end{aligned}
$$

Hesaplamaya göre etkin faiz oranı \%21,3 olarak bulunmuştur. Vadenin 4 ay olduğu göz önünde bulundurulduğunda ilgili aylara isabet eden faiz gideri tutarları Tablo 3 'te gösterilmiştir.

Tablo 3, İlgili Aylara Ait Faiz Giderleri

\begin{tabular}{lccccc}
\hline Dönem & Vade & $\begin{array}{c}\text { Etkin Faiz } \\
\text { Oranı }\end{array}$ & $\begin{array}{c}\text { Kümülatif Faiz } \\
\text { Tutarı }\end{array}$ & $\begin{array}{c}\text { Döneme Ait } \\
\text { Faiz Tutarı }\end{array}$ & $\begin{array}{c}\text { İndirgenmiş } \\
\text { Tutar }\end{array}$ \\
\hline 31.03 .2020 & 122 & 0,213 & $2.602,46$ & $2.602,46$ & $157.397,54$ \\
30.04 .2020 & 91 & 0,213 & $5.080,67$ & $2.478,21$ & $154.919,33$ \\
31.05 .2020 & 61 & 0,213 & $7.519,85$ & $2.439,18$ & $152.480,15$ \\
30.06 .2020 & 30 & 0,213 & $10.000,00$ & $2.480,15$ & $150.000,00$ \\
TOPLAM & & & $\mathbf{1 0 . 0 0 0 , 0 0}$ & $\mathbf{1 0 . 0 0 0 , 0 0}$ & $\mathbf{1 5 0 . 0 0 0 , 0 0}$ \\
\hline
\end{tabular}

İşletmenin üçer aylık dönemler itibariyle finansal raporlama yaptığı düşünüldüğünde, söz konusu alıma ilişkin olarak 1.döneme isabet eden faiz gideri 2.602,46 TL, 2.dönemde gider olarak kaydedilmesi gereken tutar ise 7.397,54 TL olacaktır. 
KGK tarafından yayımlanan taslak hesap planına göre, itfa edilmiş maliyeti üzerinden ölçülmesi gereken senetli veya senetsiz ticari borçlara ilişkin olarak dönemde ortaya çıkan faiz ve vade farkı giderlerinin izlenmesi için "650 Ticari Borçlara İlişkin Vade Farkı Giderleri ve Esas Faaliyetlerle İlgili Kur Farkı Zararları" hesabının kullanımı öngörülmüştür. Bu durumda alım sırasında "Ertelenmiş Vade Farkı Giderleri Hesabı"na kaydedilmiş olan 10.000 TL'nin ilgili 3 aylık döneme isabet eden tutarının aşağıdaki gibi kaydedilmesi gerekmektedir.

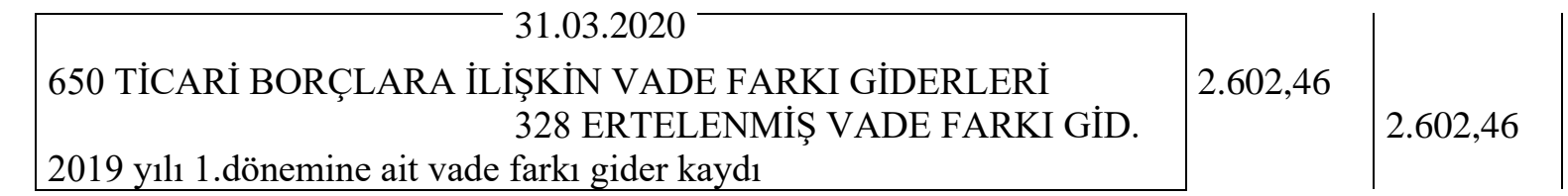

2020 yılı 2.döneminde de aynı kaydın yapılarak söz konusu döneme isabet eden tutar olan 7.397,54 TL'nin gider olarak kaydının yapılması gerekmektedir.

VUK hükümlerine göre satın alma esnasında ortaya çıkan faiz giderlerinin satın alınan stokun maliyetine dahil edilmesi, başka bir ifadeyle stokun tamamı satılıncaya kadar faiz tutarının dönem gideri olarak ticari kârdan düşülmemesi ve bu durumda ortaya çıkan ertelenmiş vergi etkisinin aşağıdaki gibi kaydedilmesi gerekmektedir (Öztürk, 2017).

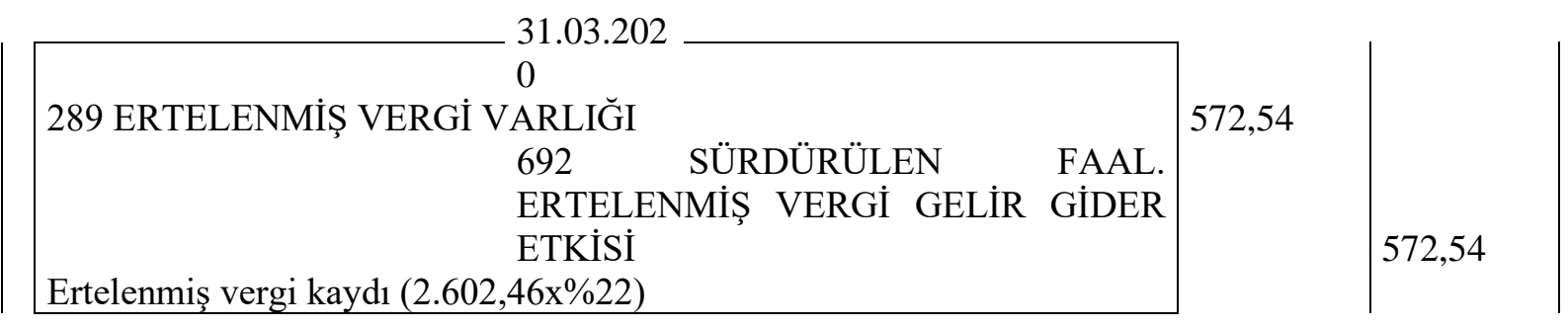

Örnek: Tekstil ürünleri imalatı yapan işletme, üretimde kullanmak üzere \%8 KDV hariç 250.000 TL tutarında olan hammaddeyi 01.07.2020 tarihinde 18 ay vadeli bir senet karşılı̆̆ında satın almıştır. KDV tutarı aynı tarihte banka hesabından yapılan eft ile ödenmiştir. Senedin üzerinde yazılı olan faiz oran $1 \% 18$ 'dir.

VUK'a göre yapılması gereken kayıt;

\begin{tabular}{|c|c|c|}
\hline 150 İLK MADDE VE MALZ. & 250.000 & \\
\hline 191 İNDİRİLECEK KDV & 20.000 & \\
\hline 102 BANKALAR & & 20.000 \\
\hline 421 BORÇ SENETLERİ & & 250.000 \\
\hline Senet karş1lığ1 mal alımı & & \\
\hline
\end{tabular}

Satın almanın bir yıldan uzun vadeli bir ödeme aracı ile yapılmış olmasından dolayı bir önceki örnekten farklı olarak BOBİ FRS'ye göre ortaya çıkan vade farkının TMS'ye benzer olarak gider olarak kaydedilmesi gerekmektedir. Gider kaydedilecek olan faiz tutarının hesaplanabilmesi için ödemeye konu olan tutarın bugünkü değerinin hesaplanması gerekmektedir. 
Bugünkü Değer= $\frac{A}{(1+n)^{(t)}}$

Formülde n, etkin faiz oranını; $\mathrm{t}$ ise vadeyi ifade etmektedir. Buna göre;

B.D. $=\frac{250.000}{(1+0,18)^{18 / 12}}$

B.D. $=250.000 / 1,2818$

\section{B.D. $=195.037 T L$}

$\mathrm{Bu}$ durumda satın almanın içerdiği finansman maliyetinin tutarı ise $250.000-195.037=54.963$ TL olacaktır. İşletmenin üçer aylık dönemler itibariyle finansal raporlama yaptığı göz önünde bulundurulduğunda ilgili dönemlere isabet eden faiz gideri tutarları Tablo 4'te gösterilmiştir.

Tablo 4. İlgili Dönemlere Ait Faiz Giderleri

\begin{tabular}{llllll}
\hline Dönem & $\begin{array}{l}\text { Vade } \\
\text { (Ay) }\end{array}$ & $\begin{array}{l}\text { Etkin } \\
\text { Oranı }\end{array}$ & $\begin{array}{c}\text { Faiz } \\
\text { Tümülatif Faiz }\end{array}$ & $\begin{array}{l}\text { Döneme } \\
\text { Faiz Tutarı }\end{array}$ & $\begin{array}{l}\text { Ait } \\
\text { Tutndirgenmiş } \\
\text { Tutar }\end{array}$ \\
\hline 30.09 .2020 & 18 & 0,18 & $10.133,55$ & $10.133,55$ & $239.866,45$ \\
\hline 31.12 .2020 & 15 & 0,18 & $19.856,35$ & $9.722,80$ & $230.143,65$ \\
\hline 31.03 .2021 & 12 & 0,18 & $29.185,03$ & $9.328,68$ & $220.814,97$ \\
\hline 30.06 .2021 & 9 & 0,18 & $38.135,59$ & $8.950,56$ & $211.864,41$ \\
\hline 30.09 .2021 & 6 & 0,18 & $46.723,34$ & $8.587,75$ & $203.276,66$ \\
31.12 .2021 & 3 & 0,18 & $54.963,00$ & $8.239,66$ & $195.037,00$ \\
\hline TOPLAM & & & $\mathbf{5 4 . 9 6 3 , 0 0}$ & $\mathbf{5 4 . 9 6 3 , 0 0}$ & $\mathbf{1 9 5 . 0 3 7 , 0 0}$ \\
\hline
\end{tabular}

Yapılan hesaplamalar doğrultusunda TMS ve BOBİ FRS'ye göre yapılması gereken kayıt;

\begin{tabular}{|c|c|c|}
\hline . 01 & & \\
\hline 150 İLK MADDE VE MALZ. & $195.037,00$ & \\
\hline 191 İNDİRİLECEK KDV & $20.000,00$ & \\
\hline 328 ERTELENMİŞ VADE FARKI GİDERLERİ & $19.856,35$ & \\
\hline 428 ERTELENMIŞ VADE FARKI GİDERLERİ & $35.106,65$ & \\
\hline 102 BANKALAR & & $20.000,00$ \\
\hline 421 BORÇ SENETLERİ & & 0 \\
\hline Senet karşılığı mal alımı & & \\
\hline
\end{tabular}

Alım sırasında “Ertelenmiş Vade Farkı Giderleri Hesabı”na kaydedilmiş olan 54.963,00 TL’nin ilgili 3 aylık döneme isabet eden kısmı aşağıdaki gibi kaydedilebilir.

30.09 .20

20

650 TİCARİ BORÇLARA İLIŞKIIN VADE FARKI GIDERLERİ

$10.133,55$

328 ERTELENMISS VADE FARKI

GIDERLERI

$10.133,55$

2019 yıl1 3.dönemine ait vade fark1 gider kayd1 
2020 yıl1 4.döneminde ve takip eden dönemlerde de aynı kaydın yapılarak söz konusu döneme isabet eden faiz tutarlarının dönem gideri olarak kaydedilmesi gerekmektedir.

VUK hükümlerine göre satın alma esnasında ortaya çıkan faiz giderlerinin satın alınan stokun maliyetine dahil edilmesi, başka bir ifadeyle stokun tamamı satılıncaya kadar faiz tutarının dönem gideri olarak ticari kârdan düşülmemesi ve bu durumda ortaya çıkan ertelenmiş vergi etkisinin aşağıdaki gibi kaydedilmesi gerekmektedir.

30.09.20

20

289 ERTELENMIȘ VERGİ VARLIĞI

692

ERTELENMIŞ VERGI GELIR GIDER ETKISI

Ertelenmiş vergi kaydı $(10.135,55 \mathrm{x} \% 22)$

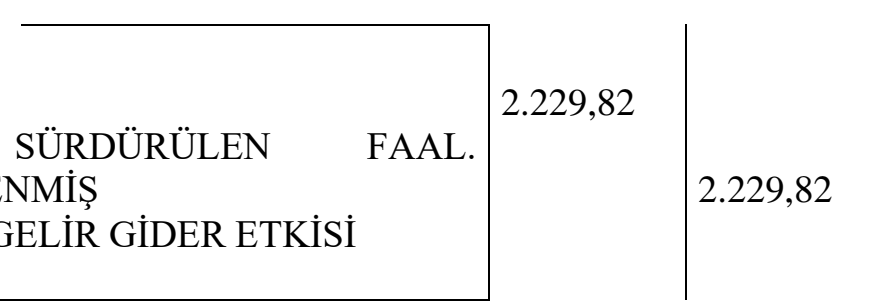

Vadeli stok ediniminde göz önünde bulundurulması gereken başka bir farklılık ise özellikli varlıklarda ortaya çıkmaktadır. TMS 23'e göre özellikli varlık, “amaçlanan kullanıma veya satı̧̧a hazır duruma getirilebilmesi zorunlu olarak uzun bir süreyi gerektiren varlıklardır" (md.5). Benzer bir durum BOBİ FRS için de geçerli olmakla birlikte BOBİ FRS'de özellikli varlık kavramından söz edilmemekte, üretilmesi normal şartlar altında bir yıldan uzun süren stoklar ifadesi yer almaktadır. VUK'ta özellikli varlık ayrımı yapılmamakta olup TMS ve BOBİ FRS’ye göre özellikli varlıklarda ortaya çıan borçlanma maliyetlerinin muhasebeleştirilmesi Tablo 5'te gösterilmiştir (Kıymetli Şen ve Özbirecikli, 2018).

Tablo 5. Özellikli Varlık Niteliğindeki Stoklarda Borçlanma Maliyetlerinin Muhasebeleştirilmesi

\begin{tabular}{lll} 
Stok & TMS & BOBं FRS \\
\hline Satışa Hazır Hale Getirildiği Tarihe Kadar & Maliyet & Maliyet \\
\hline Satışa Hazır Hale Getirildikten Sonra & Gider & Gider
\end{tabular}

TMS 23'e göre işletmelerce, "bir özellikli varlığın elde edilmesi, inşası veya üretimi ile doğrudan ilişkilendirilebilen borçlanma maliyetleri, ilgili özellikli varlı̆̆ın maliyetinin bir parçası olarak aktifleştirilir. İşletmeler, diğer borçlanma maliyetlerini oluştukları dönemde gider olarak muhasebeleştirirler" (TMS 23, md.8). Özellikli varlığın üretimi ile doğrudan ilişkilendirilebilen borçlanma maliyeti, ilgili varlıkla ilişkili harcamaların hiç yapılmamış olması durumunda ortaya çıkmayacak borçlanma maliyetleridir. Buna ilave olarak söz konusu varlığın amaçlanan kullanıma veya satışa hazır duruma getirilmesi için gerekli tüm işlemler tamamlandığında ise borçlanma maliyetleri ilgili dönem gideri olarak muhasebeleştirilir (TMS 23, md.10).

BOBİ FRS’ye göre stoklara ilişkin borçlanma maliyetleri vadenin bir yıldan uzun olması halinde oluştukları dönemde kâr veya zarara yansıtılır. Ancak, üretilmesi normal şartlar altında bir yıldan daha uzun süren stokların elde edilmesiyle doğrudan ilişkili borçlanma maliyetleri, söz konusu stokun satışa veya kullanıma hazır hale geldiği tarihe kadar stok maliyetine dâhil edilirken sonrasında ortaya çıkan borçlanma maliyetleri ilgili dönem gideri olarak kaydedilir (Bobi FRS 6.9). 
Örnek: Savunma sanayii ekipmanları üretimi yapan işletme, Millî Savunma Bakanlığının açmış olduğu ihaleyi kazanmış ve üretim süreci 16 ay sürmesi planlanan işe başlamıştır. İşletme, söz konusu siparişin üretimi için gerekli finansmanın bir kısmını öz kaynaklarıyla bir kısmını da banka kredisi kullanarak yapmayı planlamaktadır. Bu amaçla işletme 31.08.2020 tarihinde bankadan 12 ay vadeli \%1,49 faizli 1.000.000 TL kredi sağlamıştır. Yapılan kredi anlaşmasın göre kredinin aylık taksit tutarı 93.333 TL olup, kredinin toplam maliyeti 1.119.996 TL'dir. Kredi ödeme planına göre 30.09.2020 tarihinde ödenmesi gereken tutarın 74.453 TL'si anapara, kalan 18.880 TL'lik kısmı ise faizdir.

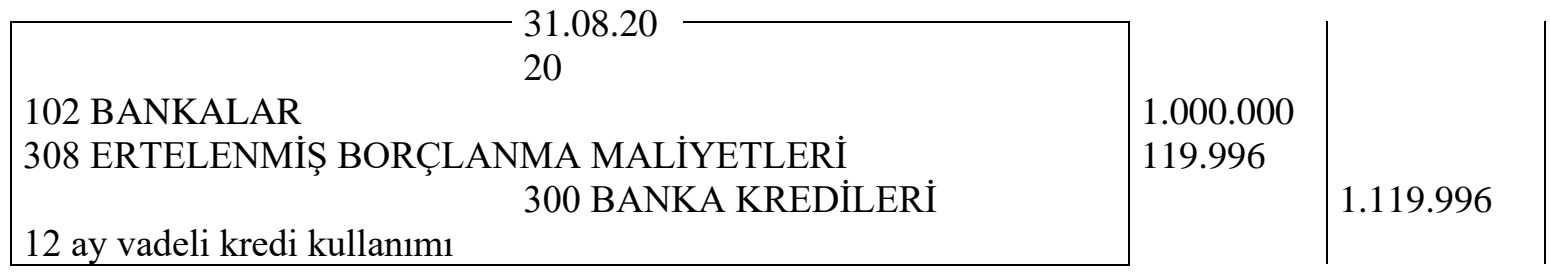

KGK tarafından yayımlanan taslak hesap planına göre finans kuruluşlarından kullanılan kredilerin muhasebeleştirilmesinde iki farklı yöntem önerilmektedir. Birinci yöntemde bankaya olan kredi borcunun anaparayla birlikte faiz de dahil olmak üzere izlenmesidir. Bu durumda gelecek dönemlerde ortaya çıkacak faiz maliyetlerinin izlenmesi için "308 Ertelenmiş Borçlanma Maliyetleri” hesabının kullanımı öngörülmüştür.

Kullanılmış olan kredinin 30.09.2020 tarihinde ödenmesi gereken ilk taksitinin muhasebe kaydı aşağıdaki gibi olacaktır.

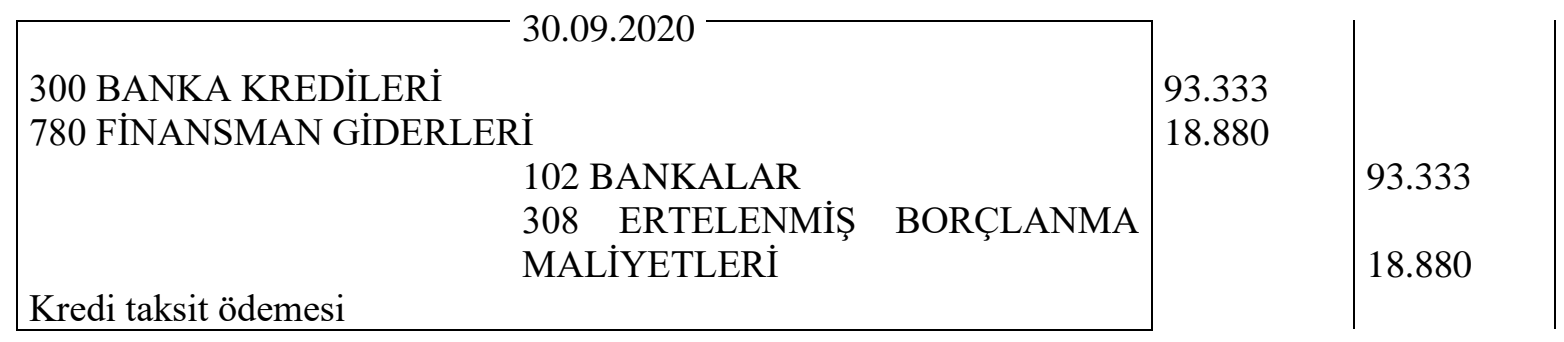

Üretimi yapılan mamulün özellikli varlık niteliğinde olmasından dolayı gider olarak kaydı yapılan faizin TMS ve BOBİ FRS'ye göre ilgili varlığın maliyetine dahil edilmesi gerekmektedir. Aynı durum VUK için de geçerli olup bu noktada düzenlemeler arasında herhangi bir farklılık bulunmamaktadır.

\begin{tabular}{|cc|}
\hline 151 YARI MAMULLER & 30.09 .2020 \\
& 781 FINANSMAN GID. YANSITMA \\
& HS. \\
2019 y1l1 3.dönemi faiz giderinin maliyeti eklenmesi
\end{tabular}




\subsubsection{Kur Farkları}

Gerek yurtiçinde yerleşik firmalardan döviz karşı1lı̆ı mal alımı ve gerekse ithalat kapsamında ürün alımı yapılması durumunda satın almanın gerçekleştiği tarih ile ödemenin yapıldığı tarih arasında döviz kurundaki değişimlere paralel olarak kur farkı ortaya çıkmaktadır. Ortaya çıkan kur farklarının muhasebeleştirilmesinde TMS, BOBİ FRS ve VUK açısından küçük de olsa birtakım farklılıklar bulunmaktadır.

Vergi uygulamaları bakımından, stokların işletme aktifine dahil edildiği tarihe kadar oluşan kur farkının stok maliyetine dahil edilmesi gerekirken, stokların işletme aktifine girmesinden sonra ortaya çıkan kur farklarının stok maliyetine dahil edilmesi ya da dönem gideri olarak kaydedilmesi ise işletmelerin tercihine bırakılmıştır (VUK Genel Tebliği, No:238: B).

TMS 21 Kur Değişiminin Etkileri standardına göre ise yabancı parayla yapılan işlemin ilk muhasebeleştirme sırasında işlem tarihindeki geçerli kur üzerinden kayıt yapılması gerekmektedir (TMS 21, md.21). Ayrıca ilgili standarda göre ortaya çıkan kur farkları oluştukları dönemde kâr veya zararda muhasebeleştirilir (TMS 21, md.28). Ancak yabancı para ile borçlanmalarda ortaya çıkan kur farkı, faiz maliyetleri ile ilgili düzeltme olarak dikkate alındıkları ölçüde olmak üzere, borçlanma maliyetleri arasında sayılabilir (TMS 23, md.6). Bu durumda standartlara göre özellikli varlık niteliğinde olan stok edinimlerinde borçlanma maliyeti ile ilişkili olan kur farkının stok maliyetine eklenmesi gerekmektedir. Standartlara ve VUK'a göre kur farklarının muhasebeleştirilme ilkeleri Tablo 6' da gösterilmiştir.

Tablo 6. Kur Farklarının Muhasebeleştirilmesi

Stok

\section{TMS/BOBI FRS VUK}

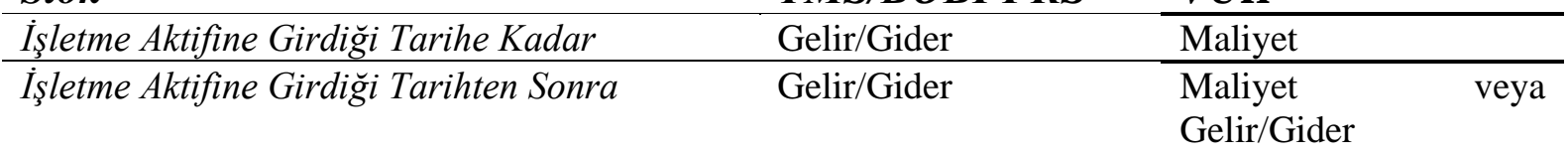

Tablo 6'da görüldüğü üzere TMS ve BOBİ FRS'ye göre kur farklarının gider olarak kaydedilmesi gerekmektedir. Ancak, stok kaleminin özellikli varlık niteliğinde olması halinde durum farklılaşmaktadır. Bu durumda hem TMS hem de BOBİ FRS açısından borçlanma maliyeti içerisinde değerlendirilebilecek kur farkının, ilgili stok kaleminin satışa hazır hale gelmesinden önce ortaya çıkması halinde maliyete ilave edilmesi; satışa hazır hale gelmesinden sonra ortaya çıkması durumunda ise dönem kâr veya zararı ile ilişkilendirilmesi gerekmektedir (Selvi ve Ercan, 2018).

Örnek: Bilişim ürünleri ticareti yapan işletme, uluslararası bir markanın ürünlerini Türkiye distribütöründen almak üzere ilgili firmayla anlaşma yapmıştır. Satın alınacak ürünlerin \%18 KDV hariç tutarı 120.000 \$'dır. Firmayla yapılan anlaşma gereği 100.000 \$ avans olarak 10.01.2020 tarihinde döviz tevdiat hesabından transfer edilerek ödenmiştir. Bu tarihte $1 \$=5,46$ TL'dir. Alış bedelinin kalan kısmı olan 20.000 \$ ile alış KDV tutarı ise ürünlerin teslim alındığ 30.01 .2020 tarihinde ödenmiştir. Bu tarihte $1 \$=5,28 \mathrm{TL}$ 'dir. 
Avansın ödenmesi ile ilgili kayıt, tüm düzenlemeler için aynı şekilde olacaktır.

\begin{tabular}{|l|l|}
$\begin{array}{l}10.01 .2020 \\
159 \text { VERILEN SIPARIŞ AVANSLARI } \\
102 \text { BANKALAR } \\
\text { Ürün alımı için avans verilmesi }(100.000 \times 5,46)\end{array}$ & 546.000 \\
\end{tabular}

Ürünlerin teslim alınarak, bedelinin ödenmesi ile ilgili kayıt TMS ve BOBİ FRS'ye göre aşağıdaki gibi olacaktır.

\begin{tabular}{|c|c|c|}
\hline 30.01 .2020 & & \\
\hline 153 TİCARİ MALLAR & 633.600 & \\
\hline 191 İNDİRİLECEK KDV & 114.048 & \\
\hline $\begin{array}{l}650 \text { TİC.BORÇLARA İLİ̧̧KİN VADE FARKI GİD. VE } \\
\text { ESAS FAAL.İLGİİ KUR FARKI GİDERLERİ }\end{array}$ & 18.000 & \\
\hline 102 BANKALAR & & 219.648 \\
\hline 159 VERILEEN SİPARİŞ AVANSLARI & & 546.000 \\
\hline $\begin{array}{l}\text { Siparişin teslim alınması ve kalan ödemenin yapılması. } \\
(20.000 \times 5,28=105.600+633.600 \times 0,18=114.048)=219.648 \\
(120.000 \times 5.28=633.600)\end{array}$ & & \\
\hline
\end{tabular}

TMS ve BOBİ FRS'ye göre avansın verildiği tarih ile ürünlerin teslim alındığı tarih arasında ortaya çıkan $(5,46-5,28)$ kur farkının $(100.000$ x 0,18) ilgili dönem gideri olarak kaydedilmesi gerekmektedir. Söz konusu tutar gider olarak kaydedildiği ve vergi kanunlarına göre gider olarak kabul edilmediği için ertelenmiş vergi etkisinin de aşağıdaki gibi kaydedilmesi gerekecektir.

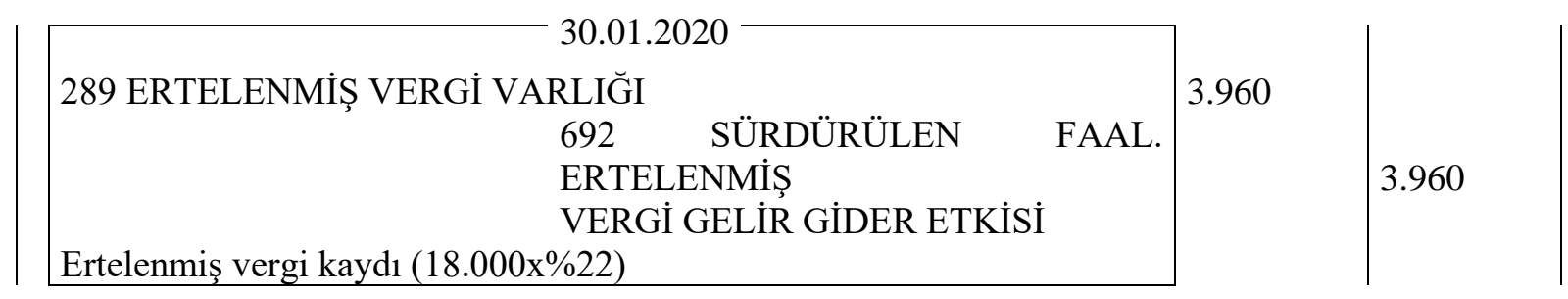

VUK'a göre söz konusu kaydın aşağıdaki gibi yapılması gerekmektedir.

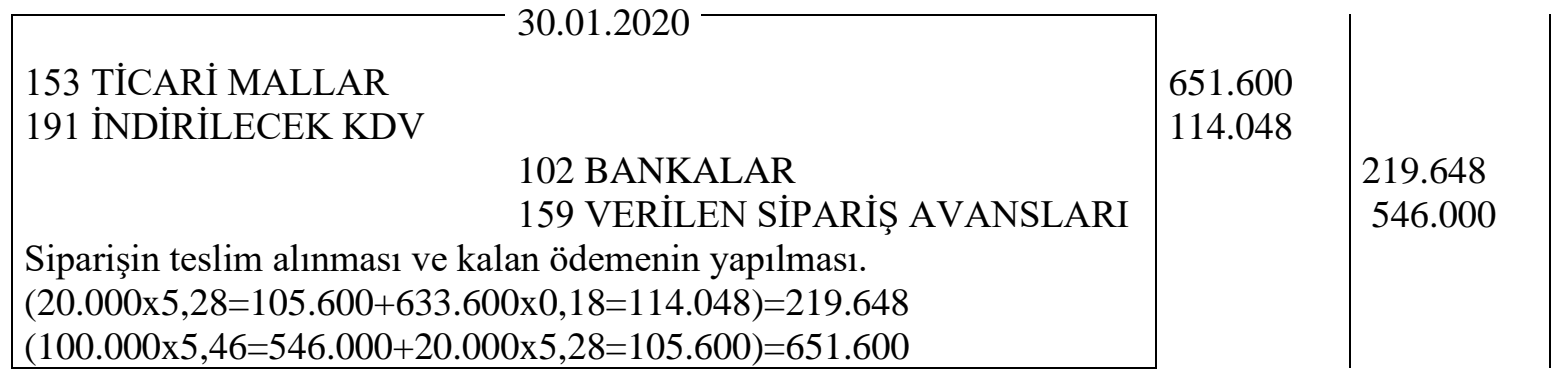

Ülkemiz vergi uygulamaları açısından stokların aktife girdiği tarihe kadar ortaya çıkan olumsuz kur farkının ilgili stokun maliyetine eklenmesi gerekmektedir. Bu bakımdan kur farkı tutarı olan 18.000 TL ticari malın maliyetine dahil edilmiştir. 


\subsubsection{Alış İskontoları}

Ticari hayatta alım satıma konu olan malların fiyatlarında bazı durumlarda indirim yapılması mümkündür. İndirim, bazı durumlarda malın alışı esnasında yapılmaktadır. Bu durumda herhangi bir düzeltici kaydın yapılmasına gerek kalmadan doğrudan indirimli fiyat üzerinden alış kaydının yapılması gerekmektedir. Ancak, erken ödeme veya belirli bir satış hacmine ulaşılması gibi durumlarda sonradan da indirim yapılması mümkün olmaktadır. Vadeden önce ödeme yapılması durumunda ortaya çıkan indirime kasa iskontosu, belirli bir satış hacminin aşılması durumunda yapılan indirime ise miktar iskontosu denilmektedir (Demir, 2015).

TMS 2 ve BOBİ FRS'ye göre ticari iskontolar ve benzeri diğer indirimler, satın alma maliyetinin belirlenmesinde indirim konusu yapılmaktadır. Bu bakımdan standartlara göre kasa iskontosu elde edilmesi durumunda vade farkı uygulamasına paralel olarak, vade farkının dönem gideri kaydedilmesi halinde kasa iskontosunun da gelir kaydedilmesi; vade farkının maliyete dahil edilmesi gereken durumlarda ortaya çıkan iskonto tutarının ise maliyetten düşülmesi gerekmektedir (Özbirecikli vd., 2017). Vergi mevzuatımıza göre ise vade farkının maliyete ilave ediliyor olmasından dolayı kasa iskontolarının da mevcut mal maliyetinden veya malların satılmış olması halinde satılan mal maliyetinden düşülmesi gerekmektedir (Özerhan ve Yanık, 2015).

Örnek: Toptan tekstil ürünleri satış1 yapan işletme, peşin fiyatı \%8 KDV hariç 100.000 TL olan malı, 3 ay vadeli 105.000 TL'ye 31.08.2020 tarihinde satın almıştır. KDV tutarı alım esnasında banka havalesi yoluyla ödenmiştir. İşletme üçüncü ayın sonunu beklemeden 10.10.2020 tarihinde ödeme yapmış olmasından dolayı satıcı firmayla yapılan anlaşma gereği 3.000 TL iskonto sağlamıştır.

Hem VUK, hem de vadenin bir y1ldan kısa olması sebebiyle BOBİ FRS'ye göre borçlanma maliyetinin stok maliyetine ilave edilmiş olmasından dolayı sağlanan iskonto tutarının stok maliyetine indirim olarak yansıtılması gerekmektedir. Bu bakımdan VUK ve BOBİ FRS'ye göre iskontoya ilişkin yapılması gereken kayıt;

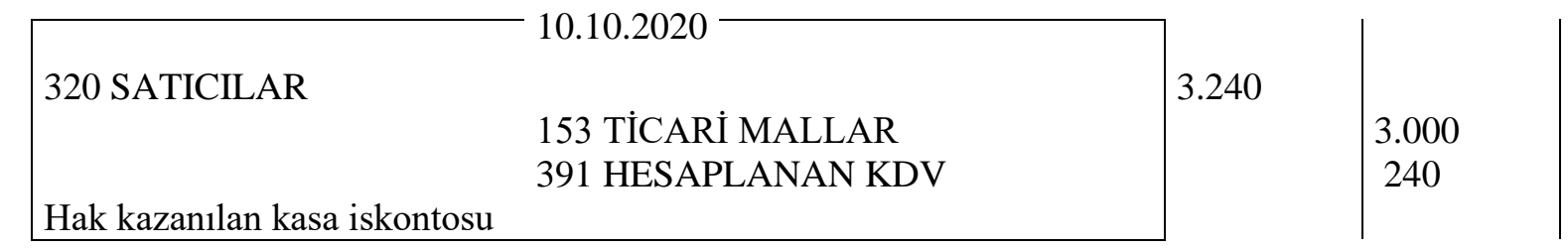

TMS 2 Stoklar standardına göre alışta ortaya çıkan borçlanma maliyetinin dönem gideri olarak kaydedilmesi gerekmektedir. 


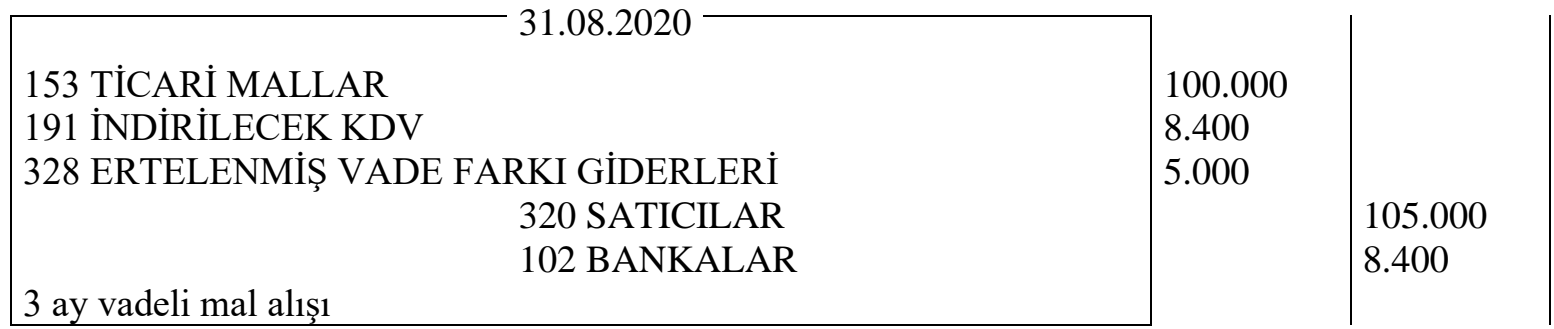

Buna ilave olarak söz konusu vade farkı tutarının ilgili döneme ait olan kısmının etkin faiz yöntemine göre cari dönem giderine dahil edilmesi gerekmektedir. Bunun için öncelikle etkin faiz oranının hesaplanması gerekmekte olup faiz oranı aşağıdaki gibi hesaplanabilir;

$$
\text { Bugünkü Değer= } \frac{A}{(1+n)^{(t)}}
$$

Formülde n, etkin faiz oranını; $t$ ise vadeyi ifade etmektedir. Buna göre;

$$
\begin{aligned}
& 100.000=\frac{105.000}{(1+n)^{3 / 12}} \\
& (1+n)^{3 / 12}=105.000 / 100.000 \\
& 1+n=\sqrt[8]{1,05^{12}} \\
& n=1,2155-1 \\
& n=0,2155
\end{aligned}
$$

Hesaplamaya göre etkin faiz oran1 \%21,6 olarak bulunmuştur. Bu durumda İşletmenin üçer aylık dönemler itibariyle finansal raporlama yaptığı düşünüldüğünde 30.09.2020 tarihi itibariyle söz konusu alıma ilişkin olarak 1 aylık döneme isabet eden faiz gideri 1.694 TL olacaktır.

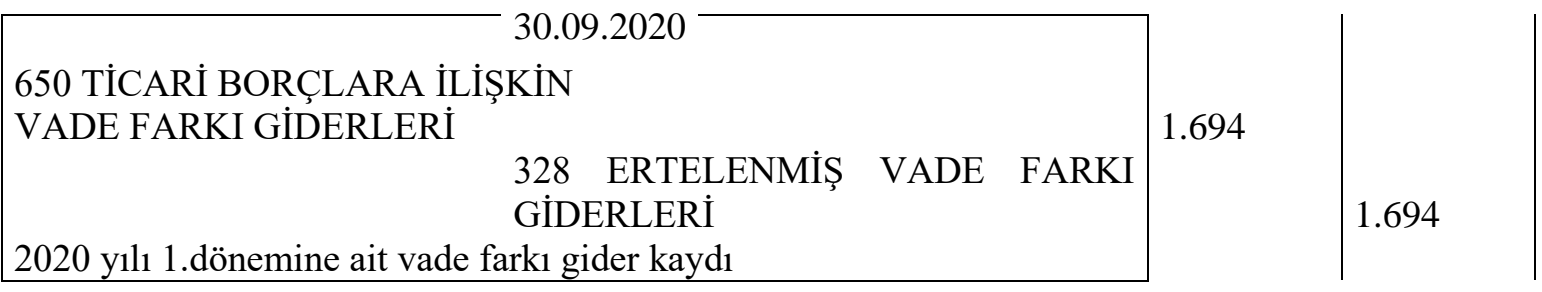

Borç tutarının erken ödenmesi nedeniyle hak kazanılan kasa iskontosu ile ilgili yapılması gereken kayit;

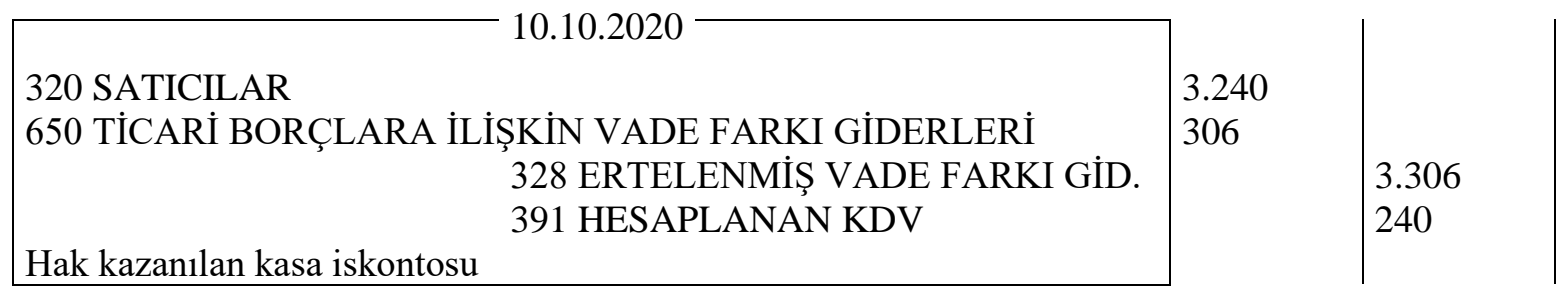


Yukarıda yapılan kayıtta, toplam faiz tutarı olan 5.000 TL'den daha önce dönem giderine kaydedilmiş olan faiz gideri tutarı olan 1.694 TL düşüldükten sonra ertelenmiş vade farkı gideri olarak kayıtlı bulunan 3.306 TL, bakiye borç ödendiği için kapatılmıştır.

Ciro primi olarak da adlandırılan miktar iskontosunda ise durum biraz daha farklıdır. 26 seri numaralı KDV Genel Tebliğinde de belirtildiği üzere miktar iskontosu, dönem sonlarında veya belirli bir ciro tutarı aşıldığında yapılan indirimlerden ibarettir. Bu sebeple bu indirim, doğrudan satışa konu olan malla ilgili değildir. Firmanın yaptığı ek bir çalışmanın ya da çabanın sonucu olarak ortaya çıkmaktadır. Bu sebeple yapılan iş ana firmaya karşı verilen bir hizmettir. Çünkü ana firma ile satıcı firma arasında düzenlenen sözleşmeye göre satıcı firma sözleşmenin hükümlerine uygun olarak belli bir çabayı göstermiş ve iskontoya hak kazanmıştır (KDV Genel Tebliği, No:26: L/2). Bu bakımdan gerek standartlara ve gerekse de vergi uygulamalarına göre alış işleminden sonra yapılan miktar iskontolarının doğrudan gelir kaydedilmesi gerekmektedir.

Örnek: Hazır gıda ürünleri satış1 yapan işletme, bayiliğini yaptığı ürünlerin satışı için 2020 yılında y1llık ürün kotası olan 100.000 birimi tamamladığı için yıl sonunda 10.800 TL ciro primine hak kazanmıştır. Satıcı firma, yıl sonunda iskonto tutarının mevcut alacağından mahsup edildiğini ve tutar için fatura gönderilmesi gerektiğini bildirmiş, bunun üzerine söz konusu tutar satıcı firmaya fatura edilmiştir.

Vergi uygulamaları ile TMS ve BOBİ FRS açısından işlemin aşağıdaki gibi muhasebeleştirilmesi gerekmektedir.

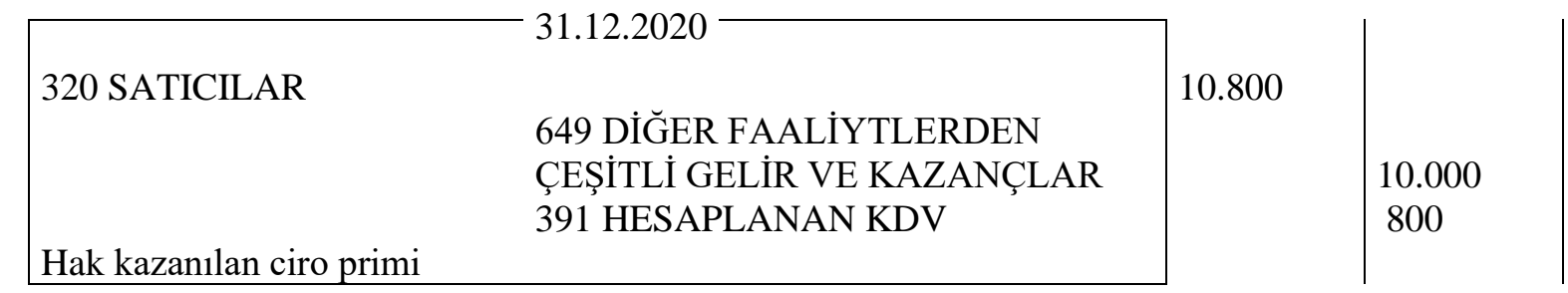

Miktar iskontosunun muhasebeleştirilmesinde, iskonto bedelinin stok maliyetinden düşülmesi gibi farklı uygulamalar mevcuttur. Ancak, vergi uygulamaları açısından KDV genel tebliğinde yer alan hükme göre tutarın dönem geliri olarak kaydedilmesi gerektiği aşikârdır (Özerhan ve Sultanoğlu, 2018). Ayrıca TMS ve BOBİ FRS açısından iskonto tutarının maliyetin belirlenmesinde indirim konusu yapılabilmesi için söz konusu iskontonun alış esnasında ortaya çıkmış olması gerektiği düşünülmektedir.

\subsection{Dönüştürme Maliyetleri}

TMS 2'ye göre mamul maliyeti, direkt ilk madde ve malzeme giderleri ile direkt iş̧ilik giderlerine ilave olarak ilk madde ve malzemenin mamule dönüştürülmesinde katlanılan sabit ve değişken genel üretim giderlerinden sistematik bir şekilde dağıtılan tutarları da içeren normal maliyet yöntemine göre hesaplanmaktadır. Sabit genel üretim giderleri, üretim tesislerinin normal kapasitesi 
esas alınarak mamul maliyetine ilave edilir. Standartta ifade edilen normal kapasite, "planlanan bakımonarım çalışmalarından kaynaklanan kapasite düşüklüğü de dikkate alınarak, normal koşullarda birkaç dönem veya sezonda elde edilmesi beklenen ortalama üretim miktarıdır”. Standarda göre mamul maliyetine eklenmeyen sabit genel üretim gideri gerçekleştiği dönemde, gider olarak finansal tablolara yansitılır (TMS 2, md.13). BOBİ FRS’ye göre dönüştürme maliyetlerinin belirlenmesinde tam maliyet yöntemi benimsenmiştir. Ancak standartta, isteyen işletmelerin normal maliyet yönteminin kullanmasına da izin verilmektedir. BOBİ FRS'ye göre dağıtılmayan genel üretim gideri, gerçekleştiği dönemde "Satışların Maliyeti” kaleminde gösterilir (Bobi FRS, 6.12-13).

VUK'a göre mamul maliyetinin hesaplanmasında kullanılması gereken yöntem ise tam maliyet yöntemidir (Doğan, 2018). Bununla birlikte VUK'un 275. maddesine göre faaliyet giderlerinden mamul maliyetine pay verilmesine de izin verilmektedir.

Örnek: Ayakkabı üretimi yapan firmanın kapasite kullanım raporuna göre normal kapasitesi aylık 20.000 çift ayakkabıdır. Firma 2020 yılı Haziran ayında 16.000 çift ayakkabı üretimi gerçekleştirmiştir. İlgili dönem üretim giderlerinin dağılımı aşağıdaki gibidir;

\begin{tabular}{ll}
\hline Maliyet Unsuru & Tutar (TL) \\
\hline Direkt İlk Madde ve Malzeme & \\
Gideri & 650.000 \\
Direkt İşçilik Gideri & 340.000 \\
Sabit Genel Üretim Gideri & 240.000 \\
Değişken Genel Üretim Gideri & 290.000 \\
TOPLAM & $\mathbf{1 . 5 2 0 . 0 0 0}$ \\
\hline
\end{tabular}

Maliyet hesaplama yöntemlerine göre birim ve toplam mamul maliyetlerini aşağıdaki gibi hesaplamak mümkündür.

\begin{tabular}{lllll}
\hline Maliyet Unsuru & Tam Maliyet & $\begin{array}{l}\text { Normal } \\
\text { Maliyet }\end{array}$ & $\begin{array}{l}\text { Değişken } \\
\text { Maliyet }\end{array}$ & $\begin{array}{l}\text { Asal (İk) } \\
\text { Maliyet }\end{array}$ \\
\hline Direkt İlk Madde ve Malzeme Gideri & 650.000 & 650.000 & 650.000 & 650.000 \\
Direkt İşçilik Gideri & 340.000 & 340.000 & 340.000 & 340.000 \\
Sabit Genel Üretim Gideri & 240.000 & 192.000 & - & - \\
Değişken Genel Üretim Gideri & 290.000 & 290.000 & 290.000 & - \\
\hline Toplam Maliyet & 1.520 .000 & 1.472 .000 & 1.280 .000 & 990.000 \\
\hline Birim Maliyet & $\mathbf{9 5 , 0 0}$ & $\mathbf{9 2 , 0 0}$ & $\mathbf{8 0 , 0 0}$ & $\mathbf{6 1 , 8 8}$ \\
\hline
\end{tabular}

VUK'a göre kullanılması gereken yöntem olan tam maliyet yöntemine göre 2020 yılı Haziran ayında üretilen mamule yüklenmesi gereken maliyet tutarı 1.520.000 TL olup, bu durumda birim mamul maliyeti 95 TL olarak gerçekleşmektedir. BOBİ FRS'ye göre de isteyen işletmeler bu maliyet hesaplama yöntemine kullanabilmektedirler. Bu durumda yapılması gereken kayıt aşağıdaki gibi olacaktır. 
30.06.2020

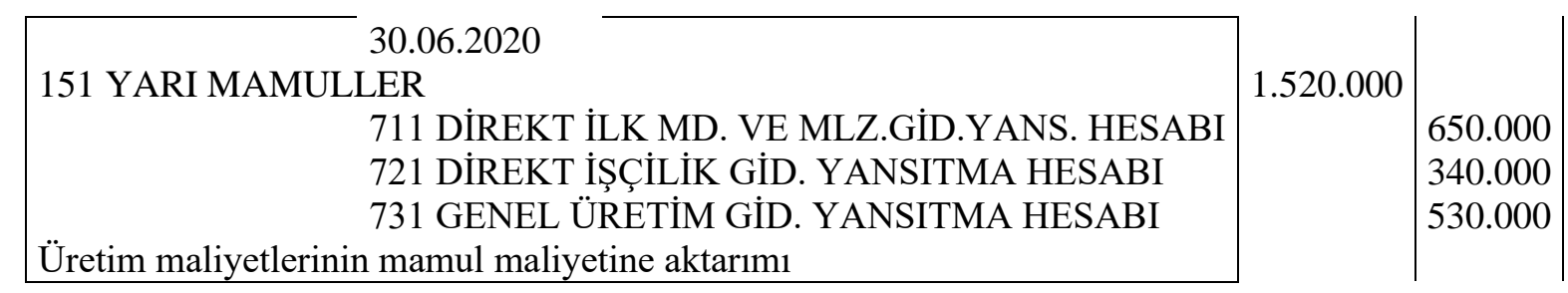

TMS'ye göre kullanılması gereken ve işletmeler tarafindan istenilmesi halinde BOBİ FRS'ye göre kullanılabilen normal maliyet yöntemine göre üretim maliyetine yüklenmesi gereken tutar 1.472.000 TL'dir. Bu yöntemde sabit genel üretim giderinden mamule pay verilebilmesi için kapasite kullanım oranının hesaplanması gerekmektedir. Firmanın normal kapasitesi 20.000 birim, fiili kapasitesi ise 16.000 birim olması nedeniyle kapasite kullanım oranı \%80 (16.000/20.000) olarak gerçekleşmiştir. $\mathrm{Bu}$ durumda sabit genel üretim giderlerinden mamule yüklenmesi gereken tutar $192.000 \mathrm{TL}$ $(240.000 x 0,80)$ olacaktır. TMS ve normal maliyet yöntemi tercih edilmesi durumunda BOBİ FRS'ye göre yapılması gereken kayıt aşağıdaki gibidir.

\begin{tabular}{|c|c|}
\hline $\begin{array}{l}151 \text { YARI MAMULLER } \\
624 \text { DAĞITILMAYAN SABİT GENEL ÜR.GID. } \\
711 \text { DİREKT İLK MD. VE MLZ. GID. YANS. HESABI } \\
721 \text { DİREKT İŞÇİLİK GID. YANSITMA HESABI } \\
731 \text { GENEL ÜRETIM GID. YANSITMA HESABI }\end{array}$ & $\begin{array}{l}1.472 .000 \\
48.000\end{array}$ \\
\hline
\end{tabular}

Normal maliyet yöntemine göre yapılan kayıtta sabit genel üretim giderinin mamul maliyeti ile ilişkilendirilmeyen kısmı olan 48.000 TL'nin (240.000-192.000) standart gereği dönem gideri olarak kayıt edilmesi gerekmektedir. Taslak hesap planına göre üretim birimlerine dağıtılmayan sabit genel üretim giderlerinin izlenmesi için "624 Dağıtılmayan Sabit Genel Üretim Giderleri Hesabı" oluşturulmuştur. TMS ve BOBİ FRS'ye göre yapılan kayda göre dönem gideri olarak kaydedilen tutar VUK açısından gider niteliğinde olmadığı için vergi uyum kaydının da ayrıca yapılması gerekmektedir.

\subsection{Diğer Maliyetler}

TMS 2 ve BOBİ FRS'ye göre sadece stokların mevcut duruma ve konumuna getirilmesi için katlanılan giderler stok maliyetlerine eklenir (Bobi FRS 6.14; TMS 2 md.15). Bu tür maliyetler, sadece stokların mevcut konumuna ve durumuna getirilmesi için katlanıldığı ölçüde stok maliyetine dâhil edilir. Ayrıca stokların mevcut konuma ve duruma getirilmesinde katkısı olmayan genel yönetim giderleri, normalin üstünde gerçekleşen fire ve kayıplar ile satış maliyetleri mamul maliyete dahil edilmez (Bobi FRS 6.15; TMS 2 md.16). VUK uygulamaları da bu noktada standartlara paralellik göstermekle birlikte VUK'un 275. Maddesine göre genel yönetim giderlerinden mamule düşen hissenin mamulün maliyetine alınmasının isteğe bağlı bırakılması diğer maliyetler açısından tek farklılık olarak ortaya çıkmaktadır (Yalçın, 2019). 


\subsection{Ortak ve Yan Ürünlerin Maliyetinin Belirlenmesi}

Üretim sürecinde aynı anda birden fazla ürünün ortaya çıkması durumunda ortak ürün ya da yan ürün olarak adlandırılabilecek ürünlerden söz edilmektedir. Aynı hammaddeden, aynı üretim sürecine tabi tutularak birden fazla çeşitte ortaya çıkan ürünlere ortak ürün denilmektedir. Bu ürünler, aynı üretim işlemi sonucu ortaya çıkmakta ve değerleri de benzer düzeyde olmaktadır. Üretim sürecinin belirli bir noktasında iki veya daha fazla ürün grubunun ayrılarak yeni bir üretim sürecinin başladığı noktaya ise ayrılma noktası denilmektedir. Bu noktaya kadar katlanılan maliyetlerin ayrı ayrı izlenmesi mümkün bulunmamakla birlikte bu giderler ortaktır ve bunlara birleşik giderler denilmektedir. Bu noktadan sonra ortaya çıkan maliyetlere ise ek gider denilmektedir (Karakaya, 2007). TMS 2 ve BOBİ FRS'ye göre her bir ürünün üretim maliyetinin ayrı olarak belirlenemediği durumlarda, maliyetler ürünler arasında tutarlı ve mantıklı bir şekilde dağıtılmalıdır. Bu bakımdan standartlarda kesinlikle kullanılması gereken bir yöntem belirtilmemiştir. Birleşik maliyetlerin dağıtımı ile ilgili olarak ortaya çıkan birleşik maliyetlerin, her bir ürünün ayrı olarak belirlenebilir hale geldiği üretim aşamasındaki veya üretimin tamamlandığı andaki nispi satış değerine göre yapılabileceği belirtilmiştir (Bobi FRS 6.16; TMS 2 md.14).

Yan ürün, üretimi amaçlanan mamul dışında kendiliğinden ortaya çıkan ürünlerdir. Bu ürünler miktar ve değer olarak esas ürüne kıyasla oldukça düşük düzeydedir (Gökçen ve Baysak, 2019). TMS 2 ve BOBİ FRS'ye göre yan ürünler, değerlerinin önemsiz olduğu durumlarda net gerçekleşebilir değer üzerinden ölçülür ve bu değer, ana ürünün maliyetinden düşülür. Bunun sonucu olarak ana ürünün defter değeri, maliyet değerinden önemli ölçüde farkl11ık göstermeyecektir (Bobi FRS 6.16; TMS 2 md.14).

Vergi Usul Kanununda ortak ürünlerin maliyetinin belirlenmesi ile ilgili ayrı bir düzenleme bulunmamakla birlikte 275. madde hükmüne göre imal edilen mamulün maliyetine kanunda belirtilen unsurlar ilave edilerek esas ürün maliyetinin belirlenmesine benzer bir şekilde belirlenebilir. Yan ürünlerin maliyeti konusunda da VUK'ta ayrı bir düzenleme bulunmamakta, 278. madde uyarınca emsal bedel ile değerlenmesi gerekmektedir (Yalçın, 2019).

Örnek: Şeker pancarından toz şeker üretimi yapan işletmede ana ürün olan toz şekere ilave olarak melas da ortaya çıkmaktadır. 2020 yılı Mart ayı birleşik üretim maliyetleri aşağıdaki gibidir;

$\begin{array}{lll}\text { Direkt İlk Madde ve Malzeme Gideri } & : & 550.000 \mathrm{TL} \\ \text { Direkt İşçilik Giderleri } & : & 320.000 \mathrm{TL} \\ \text { Genel Üretim Giderleri } & : & 230.000 \mathrm{TL} \\ \text { Toplam Birleşik Üretim Maliyeti } & : 1.100 .000 \mathrm{TL}\end{array}$

İşletmede ilgili dönemde 350 ton toz şeker ve 150 ton melas üretimi gerçekleştirilmiştir. Şekerin piyasa fiyat1 3.570 TL/ton, melasin piyasa fiyat1 $750 \mathrm{TL} /$ ton'dur. Ayrılma noktasından sonra melasin satışa hazır hale getirilebilmesi için katlanılan ilave maliyet tutarı ise 20.000 TL'dir. 
TMS ve BOBİ FRS'ye göre bir ürünün yan ürün olarak nitelendirilebilmesi için ortaya çıan ürünün esas ürüne kıyasla miktar ve değer olarak düşük düzeyde olması gerekmektedir. Yukarıda verilen örnekte her ne kadar miktar olarak melas üretimi çok düşük düzeyde olmamasına rağmen, değer olarak ana ürüne oranla oldukça düşük düzeyde olduğu söylenebilir. Çünkü üretilen şekerin piyasa değeri (350 ton x 3.570 TL) 1.249.500 TL iken melasın piyasa değeri ise (150 ton x $750 \mathrm{TL}) 112.500$ TL'dir. Başka bir ifadeyle piyasa değeri açısından melasın değeri, şekerin değerinin \%9'u kadardır. Bu durumda değer olarak ana ürün olan şekere oranla düşük bir değere sahip olan melasın yan ürün olarak nitelendirilmesi gerekmektedir.

\begin{tabular}{|c|c|c|}
\hline $\begin{array}{lll}151 \text { YARI MAMULLER } & & \\
& 711 \text { DIREKT ILK MD. VE } & \text { MLZ. } \\
& \text { GiD.YANS. HESABI } & \\
& 721 \text { DIREKT IŞÇILIK } & \text { GID. } \\
& \text { YANSITMA HESABI } & \\
& 731 \text { GENEL ÜRETIM } & \text { GID. } \\
\text { YANSITMA HESABI } & \\
\text { Üretim maliyetlerinin mamul maliyetine aktarım } & \end{array}$ & 1.120 .000 & $\begin{array}{l}550.000 \\
320.000 \\
250.000\end{array}$ \\
\hline $\begin{array}{l}152 \text { MAMULLER } \\
157 \text { DİĞER STOKLAR } \\
\begin{array}{l}\text { 151 YARI MAMULLER } \\
\text { Üretim maliyetlerinin mamul maliyetine aktarımı }\end{array}\end{array}$ & $\begin{array}{l}1.007 .500 \\
112.500\end{array}$ & 1.120 .000 \\
\hline
\end{tabular}

TMS ve BOBİ FRS'ye göre yan ürünlerin net gerçekleşebilir değer üzerinden ölçülmesi ve maliyetinin esas ürün maliyetinden düşülmesi gerekmektedir. Bu durumda yan ürün olan melasın gerçeğe uygun değeri şu şekilde hesaplanabilir;

Tahmini satış fiyatı

Tahmini tamamlama maliyeti

Net gerçekleşebilir değer
: $112.500 \mathrm{TL}$

: $20.000 \mathrm{TL}$

: $92.500 \mathrm{TL}$

Bu durumda birleşik maliyet tutarı olan 1.100.000 TL'den yan ürünün net gerçekleşebilir değeri olan 92.500 TL düşülerek kalan tutar olan 1.007.500 TL ana ürüne yüklenecek maliyet tutarıdır.

Örnek: Kırmızı et entegre işletmesinde 2020 yılı Mayıs ayı itibariyle elde edilen ürünler, ürünlerin satış fiyatları ve toplam satış hasılatı içindeki payları aşağıdaki gibidir.

\begin{tabular}{lllll}
\hline Ürün & $\begin{array}{l}\text { Üretim Miktarı } \\
(\mathbf{k g})\end{array}$ & $\begin{array}{l}\text { Satış Fiyatı } \\
(\mathbf{T L})\end{array}$ & $\begin{array}{l}\text { Tutar } \\
\mathbf{( T L )}\end{array}$ & $\begin{array}{l}\text { Oran } \\
(\boldsymbol{\%})\end{array}$ \\
\hline Bonfile & 5.000 & 50,00 & 250.000 & 7,68 \\
Rosto & 9.000 & 35,00 & 315.000 & 9,68 \\
Kuşbaş1 & 23.000 & 32,00 & 736.000 & 22,61
\end{tabular}




\begin{tabular}{lllll} 
Pirzola & 4.000 & 46,00 & 184.000 & 5,65 \\
Kiyma & 59.000 & 30,00 & 1.770 .000 & 54,38 \\
\hline TOPLAM & $\mathbf{1 0 0 . 0 0 0}$ & & $\mathbf{3 . 2 5 5 . 0 0 0}$ & $\mathbf{1 0 0 , 0 0}$
\end{tabular}

İşletmenin normal üretim sürecinde yukarıda yer alan ürünlere ilave olarak ortaya çıkan yan ürün miktarları, satış fiyatları ve bu ürünler için ayrılma noktasından sonra katlanılan maliyetler aşağıdaki gibidir.

\begin{tabular}{lllll}
\hline Ürün & Üretim Miktarı & $\begin{array}{l}\text { Satış Fiyatı } \\
(\mathbf{T L})\end{array}$ & $\begin{array}{l}\text { Tutar } \\
(\mathbf{T L})\end{array}$ & İlave Maliyet \\
\hline Deri & $13.000 \mathrm{~kg}$. & 4,00 & 52.000 & 5.000 \\
Sakatat & 400 takım & 350,00 & 140.000 & 10.000 \\
\hline TOPLAM & & & $\mathbf{1 9 2 . 0 0 0}$ & $\mathbf{1 5 . 0 0 0}$
\end{tabular}

İşletmenin ilgili dönemde üretim için katlandığı birleşik maliyet tutarları ise aşağıdaki gibidir;

Direkt İlk Madde ve Malzeme Gideri $\quad: 2.950 .000$ TL

Direkt İşçilik Gideri $\quad$ : $\quad 90.000 \mathrm{TL}$

Genel Üretim Gideri $\quad$ : $\quad 60.000 \mathrm{TL}$

Toplam $\quad: 3.100 .000 \mathrm{TL}$

Ortak ürünlerin üretimine yüklenecek maliyet tutarının belirlenebilmesi için yan ürünlerin net gerçekleşebilir değerinin hesaplanması gerekmektedir. Yan ürünlerin net gerçekleşebilir değeri (192.000-15.000) 177.000 TL olacaktır. Bu durumda ortak ürünlere yüklenmesi gereken birleşik maliyet tutar1 ise (3.100.000-177.000) 2.923.000 TL'dir.

Bu durumda birleşik maliyetin piyasa satış değerlerine göre ortak ürünlere dağılımı ise aşağıdaki gibi olur.

\begin{tabular}{llll}
\hline Ürün & $\begin{array}{l}\text { Birleşik Maliyet } \\
(\mathbf{T L})\end{array}$ & $\begin{array}{l}\text { Toplam Satış İçindeki Pay } \\
(\boldsymbol{\%})\end{array}$ & $\begin{array}{l}\text { Birleşik Maliyet Payı } \\
\mathbf{( T L )}\end{array}$ \\
\hline Bonfile & & 7,68 & $224.486,40$ \\
Rosto & & 9,68 & $282.946,40$ \\
Kuşbaş1 & 2.923 .000 & 22,61 & $660.890,30$ \\
Pirzola & & 5,65 & $165.149,50$ \\
Kiyma & & 54,38 & $1.589 .527,40$ \\
\hline TOPLAM & & $\mathbf{1 0 0 , 0 0}$ & $\mathbf{2 . 9 2 3 . 0 0 0 , 0 0}$
\end{tabular}

Ortak ve yan ürünlerin maliyetlerinin belirlenmesinde TMS ve BOBİ FRS tam uyumludur. VUK'ta ise yan ürünlerle ilgili bir düzenleme bulunmamakla birlikte genel olarak standart setleri ile kısmi bir uyumluluk söz konusudur. 


\subsection{Maliyet Hesaplama Yöntemleri}

TMS ve BOBİ FRS'ye göre stokların satışı veya kullanımı durumlarında maliyetinin, normal şartlarda birbirleriyle ikame edilemeyen stoklar ve özel projeler için üretilen ya da satın alınan mal ve hizmetler için gerçek parti maliyet yöntemi ile belirlenmesi önerilmektedir. Gerçek parti maliyetinin tespitinin mümkün olmadığı durumlarda ise stok kalemlerinin maliyeti, ilk giren ilk çıkar (FIFO) veya ağırlıklı ortalama maliyet yöntemlerinden biri kullanılarak hesaplanır. Standart setlerine göre ayrıca benzer niteliklere ve benzer kullanıma sahip tüm stoklar için aynı maliyet hesaplama yönteminin kullanılması gerekmekte; ancak nitelikleri veya kullanım alanları itibarıyla farklı olan stoklar için farklı maliyet hesaplama yöntemlerinin kullanılmasına izin verilmektedir (Bobi FRS 6.20; TMS 2 md.25). VUK'a göre ise stokların değerlemesinde maliyet bedeli ölçüsü kabul edilmiş ve maliyet bedelinin hesaplanmasında uygulanacak yöntemin seçiminde işletmeler serbest bırakılmıştır.

\subsection{Maliyet Ölçüm Teknikleri}

TMS ve BOBİ FRS'ye göre mamul maliyeti, üretim giderlerinin gerçekleşmiş tutarları esas alınarak fiili maliyet yöntemine göre belirlenir. Ancak sonuçlar fiili maliyete yakınsa, standart maliyet yöntemi veya perakende yöntemi gibi stok maliyeti ölçüm yöntemleri de kullanılabilmektedir. "Standart maliyet hesabında, hammadde ve malzemelerin, işçiliğin, verimliliğin ve kapasite kullanımının normal düzeyleri dikkate alınır. Standart maliyetler, düzenli olarak gözden geçirilir ve gerektiği takdirde mevcut şartlara göre yeniden belirlenir. Perakende yönteminde maliyet, stokların satış değerinden uygun brüt kâr marjının düşülmesi suretiyle bulunur” (Bobi FRS 6.19; TMS 2 md.21).

VUK'a göre işletmeler ürettikleri mamulün maliyet bedellerini ilgili maddede belirtilen maliyet unsurlarını kapsaması şartıyla diledikleri yöntemle ölçebilmektedirler. Ayrıca, VUK çerçevesinde şekillendirilmiş olan Tek Düzen Hesap Planında yer alan maliyet fark hesapları, standart maliyet yönteminin uygulanabilmesi için uygun bir altyapı da sağlamaktadır. Bu bakımdan VUK ve buna paralel olarak MSUGT'ye göre fiili maliyet yönteminin yanı sıra standart maliyet yönteminin kullanılmasına da izin verilmektedir (Selvi ve Ercan, 2018).

Örnek: Ayakkabı imalatı yapan ve maliyetlerini standart maliyet yöntemine göre hesaplayan bir işletmenin, A184 stok kodu ile üretmekte olduğu ayakkabıların standart maliyeti şu şekilde belirlenmiştir.

$\begin{array}{ll}\text { Standart Hammadde Maliyeti } & : 52 \mathrm{TL} \\ \text { Standart İşçilik Maliyeti } & : 23 \mathrm{TL} \\ \text { Standart Genel Üretim Payı } & : 12 \mathrm{TL}\end{array}$

İşletme 2020 yılı birinci döneminde söz konusu ayakkabı modelinden 5.000 çift üretmeyi planlamaktadır. Bu durumda yapılması gereken kayıt aşağıdaki gibi olacaktır. 


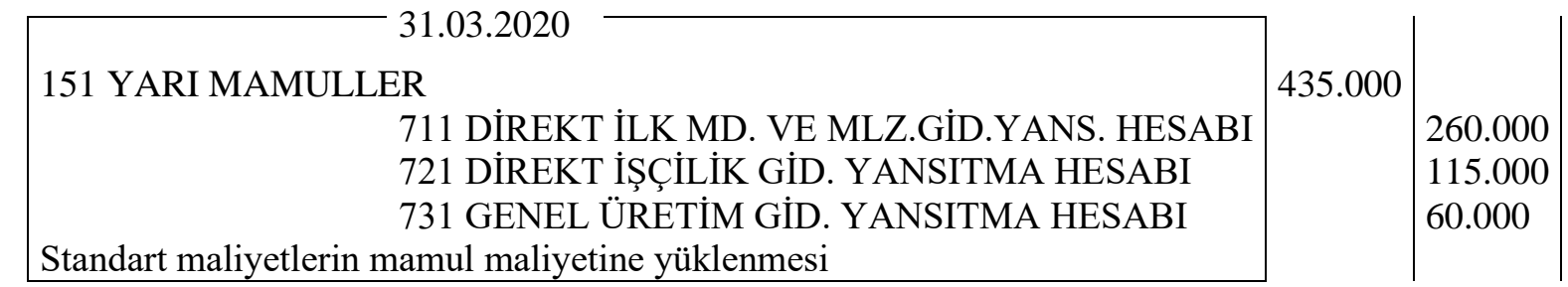

Örnek: Perakende elektronik ürün ticaret yapan bir işletme maliyet bedeli üzerinden \%20 kar marjı ile satış yapmaktadır. 2020 yılı başında stokta bulunan 75.000 TL'lik X marka/model bilgisayardan dönem içinde 285.000 TL'lik almış, 360.000 TL'lik satmıştır.

Perakende yöntemine göre satılan malın maliyeti ve dönem sonu stok tutarı aşağıdaki şekilde hesaplanır;

$\begin{array}{lll}\text { Satılan Ticari Mal Maliyeti } & : 360.000 / 1,20 & =300.000 \mathrm{TL} \\ \text { Dönem Sonu Stok } & : 75.000+285.000-300.000 & =60.000 \mathrm{TL}\end{array}$

\subsection{Stokların Dönem Sonu Değerlemesi}

Stokların raporlama dönemi sonunda değerlemesi, stokların zarar görmesi, teknolojik gelişmeler nedeniyle kısmen veya tamamen değerini kaybetmesi ya da satış fiyatının düşmesi gibi nedenlerle stok maliyetinin geri kazanılabilir olma kabiliyetinin ölçülmesi anlamına gelmektedir (Kaygusuzoğlu, 2010: 188). TMS ve BOBİ FRS'ye göre raporlama dönemi sonunda stoklar, maliyet bedeli ve net gerçekleşebilir değerin düşük olanı ile değerlenir (BOBİ FRS 6.22; TMS 2 md.28).

Gerek TMS ve gerekse BOBİ FRS'ye göre stoklar değer düşüklüğüne uğramışsa, stokların defter değeri net gerçekleşebilir değerine indirilir. Bu indirim tutarı değer düşüklüğü zararıdır ve kâr veya zararda muhasebeleştirilir (Kaya, 2018). Ayrıca standart setlerine göre "Stoklara iliş̧kin değer düşüklüğü testi genellikle her bir stok kalemi için ayrı ayrı gerçekleştirilir. Ancak bazı durumlarda, benzer veya ilişkili kalemleri gruplandırmak uygun olabilir. Örneğin, benzer amaçlara veya nihai kullanıma sahip stok kalemlerinin aynı coğrafi bölgede üretilip pazarlanması ve bu stokların değerlemesinin aynı üretim hattındaki diğer ürünlerden ayrı olarak yapılamaması durumunda gruplandırma yapılabilir” (Bobi FRS 6.23; TMS 2 md.29).

VUK'a göre stoklar, maliyet bedeli ile değerlenir. Ancak stokların maliyet bedeline göre değerleme günündeki satış bedelleri \%10 ve daha fazla bir düşüklük gösterdiği hallerde, maliyet bedeli yerine emsal bedeli ölçüsü kullanılabilir (Öztürk, 2017). Ayrıca, doğal afetler ya da bozulmak, çürümek, kırılmak, çatlamak, paslanmak gibi sebepler nedeniyle değerinde önemli bir azalış ortaya çıkan stoklar da emsal bedeli ile değerlenir. Kanuna göre emsal bedelin tespitinde değeri düşen mallar için uygulanabilen ortalama fiyat esası ve takdir komisyonunca tespit olmak üzere iki yöntem bulunmaktadır. Ancak genel uygulamada emsal bedelin tespiti için başvurulan yöntem takdir komisyonunca emsal bedel tespitidir (Özulucan ve Temel, 2020). 
KGK tarafından yayımlanan taslak hesap planına göre değer düşüklüğüne uğrayan stoklar için ayrılan karşı1ıkların izlenmesi amacıyla "626 Stok Değer Düşüklüğü Karş1lık Giderleri” hesabının kullanımı öngörülmüştür. Ayrıca karşılık ayrılan stok kalemlerinin, koşulların değişmesi nedeniyle değer düşüklüğü riski ortadan kalkması ve dolayısıyla karşılığın iptali söz konusu olduğunda ise "627 Stoklara İlişkin Konusu Kalmayan Karş1lıklar” hesabının kullanımı öngörülmüştür.

Örnek: Elektronik ürün ticareti ile uğraşan bir işletmenin stoklarında bulunan bazı ürünlerin dönem sonu itibariyle teknolojik olarak eskidiği ve satış değerinin düştügü tespit edilmiştir. Ürünlerin maliyet değeri 280.000 TL'dir. Yapılan araştırmaya göre bu ürünlerin piyasa satış değerinin 260.000 TL olduğu anlaşılmıştır. Ayrıca bu ürünlerin montaj ve nakliye bedelinin de 5.000 TL olacağı tahmin edilmiştir.

TMS ve BOBİ FRS'ye göre stoklar, raporlama dönemi sonlarında maliyet bedeli ve net gerçekleşebilir değerden düşük olanı ile değerlenmektedir. Söz konusu ürünlerin net gerçekleşebilir değeri şu şekilde hesaplanır;

Net Gerçekleşebilir Değer $=$ Tahmini Satış Fiyatı - Tahmini Tamamlama Maliyeti - Tahmini Satış Giderleri

NGD $\quad: 260.000-5.000 \quad=255.000 \mathrm{TL}$

Değer Düşüklüğü $\quad: 280.000-255.000 \quad=25.000 \mathrm{TL}$

\begin{tabular}{|l|l|}
$\begin{array}{l}31.12 .2020 \\
\text { 626 STOK DEĞER DÜŞÜKLÜĞÜ KARŞILIK GİD. } \\
158 \text { STOK DEĞER DÜŞÜKLÜĞÜ KARŞILIKLARI } \\
\text { Stok değer düşüklüğü karş1lığı ayrılması }\end{array} \mid 25.000$ & \\
\end{tabular}

VUK'a göre değer düşüklüğü ayrılabilmesi için \%10 ve üzerinde bir değer kaybının tespit edilmiş olması gerekmektedir. Örnekte ortaya çıkan değer düşüklüğü tutarı \%10'dan düşük olduğu için vergisel açıdan gider kaydı mümkün bulunmamaktadır. Bu bakımdan vergi uyum kaydının da ayrıca yap1lmas1 gerekmektedir.

Standart setlerinde ayrıca hammaddelerin ve buna paralel olarak mamullerin değerlemesi ile ilgili hüküm de bulunmaktadır. Buna göre, "bir hammadde ve malzeme kullanılarak üretilecek mamulün, maliyetinin altında satılmasının beklenmemesi durumunda bu hammadde ve malzeme için değer düşüklüğ̈̈ ayrllmaz. Ancak, ham madde ve malzemelerin fiyatlarındaki azalış, mamullerin net gerçekleşebilir değerinin maliyetinden daha düşük olacağını gösteriyorsa, hammadde ve malzemelerin değeri net gerçekleşebilir değerine düşürülür” (Bobi FRS, 6.24).

Örnek: Entegre tavuk ürünleri imalatı yapan bir işletmenin stoklarında kg'1 11 TL'den kayıtlı $20.000 \mathrm{~kg}$ hammadde stoku bulunmaktadır. Ülkede yapılan yasal düzenleme gereği tavuk eti fiyatlarının yükselmiş olması gerekçesiyle ithalatta alınan vergiler düşürülmüş ve ülkeye hammadde girişi artmıştır. 
Bu sebeple hammadde alış fiyatı 9 TL'ye düşmüş, buna bağlı olarak geçmiş dönemde 14 TL olan ürün satış fiyatı da 12 TL'ye gerilemiştir.

Hammadde fiyatlarındaki azalışın mamulün net gerçekleşebilir değerinin maliyetinden daha düşük olacağını gösterdiği için söz konusu hammaddeler için değer düşüklüğü karş1lığı ayrılması gerekmektedir. Burada ortaya çıkan değer düşüklüğü tutarı \%10’un üzerindedir. VUK açısından emsal bedel üzerinden değerlenerek değer düşüklüğü tutarının gider kaydedilmesi mümkündür.

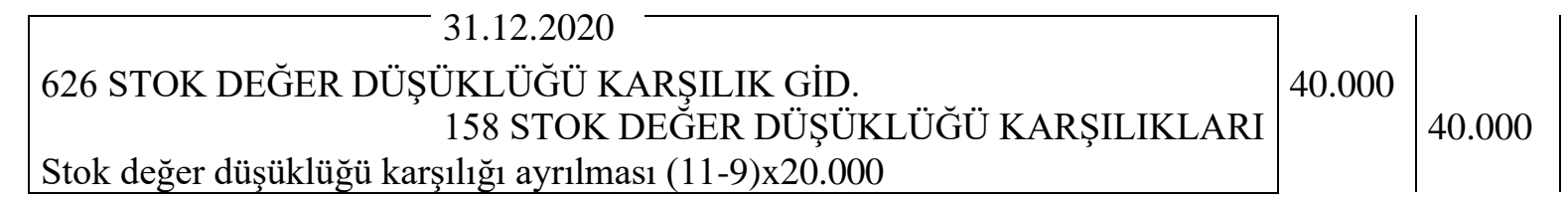

Standart setlerinde değer düşüklüğü ile ilgili bir başka düzenleme ise değer düşüklügüü karşılığının iptali ile ilgilidir. Buna göre değer düşüklüğünün ayrıldığı dönemi izleyen dönemlerde, "net gerçekleşebilir değer yeniden değerlendirilir. Daha önce stokların maliyet değerinin altına indirgenmesine neden olan koşulların artık mevcut olmaması veya değişen ekonomik koşullar nedeniyle net gerçekleşebilir değerde bir artı̧s olduğuna ilişkin açık bir kanıtın bulunması durumunda, indirgenen tutar iptal edilir". Ancak burada iptal edilen tutar, daha önce indirgenen tutarla sınırlıdır (Bobi FRS 6.25; TMS 2 md.33). Başka bir ifadeyle stokun yeni defter değeri, maliyet değeri ile revize edilmiş net gerçekleşebilir değerinden düşük olanı olur.

Örnek: Toptan demir ticareti ile uğraşan bir firmanın stoklarında birim maliyeti $2.300 \mathrm{TL}$ olan 250 ton demir bulunmaktadır. Raporlama dönemi sonunda yapılan değerlendirmeye göre inşaat sektöründe ortaya çıkan kriz sebebiyle piyasa satış değerinin 2.200 TL'ye düştüğü ve birim satış giderinin de $10 \mathrm{TL}$ olduğu tespit edilmiştir.

$$
\begin{array}{lll}
\text { Maliyet Bedeli } & : 2.300 \times 250 & =575.000 \mathrm{TL} \\
\text { Net Gerçekleşebilir Değer } & :(2.200-10) \times 250 & =547.500 \mathrm{TL} \\
\text { Değer Düşüklüğü } & : 575.000-547.500 & =27.500 \mathrm{TL}
\end{array}
$$

\begin{tabular}{|c|c|c|}
\hline $\begin{array}{l}626 \text { STOK DEĞER DÜŞÜKLÜĞÜ KARŞ̆ILIK GIID. } \\
158 \text { STOK DEG̈ER DÜŞÜKLÜĞÜ KARŞILIKLARI } \\
\text { Stok değer düsüklüğg̈ karsıl1ığ1 ayrılmas } 1\end{array}$ & 27.500 & 27.500 \\
\hline
\end{tabular}

Örnek: İnşaat sektörünün canlandırılması amacıyla devlet tarafından uygulanan reformlar sebebiyle inşaat piyasası hareketlenmiş ve önceki örnekte değer düşüklüğü karş1lığı ayrılmış olan demirin net gerçekleşebilir değeri sonraki raporlama dönemi itibariyle 2.280 TL'ye yükselmiştir.

$\begin{array}{lll}\text { Net Gerçekleşebilir Değer } & : 2.280 \times 250 & =570.000 \mathrm{TL} \\ \text { Değer Düşüklüğğ } & : 575.000-570.000= & =5.000 \mathrm{TL}\end{array}$


İptal Edilmesi Gereken Karş1lık: 27.500 - 5.000

$$
=22.500 \mathrm{TL}
$$

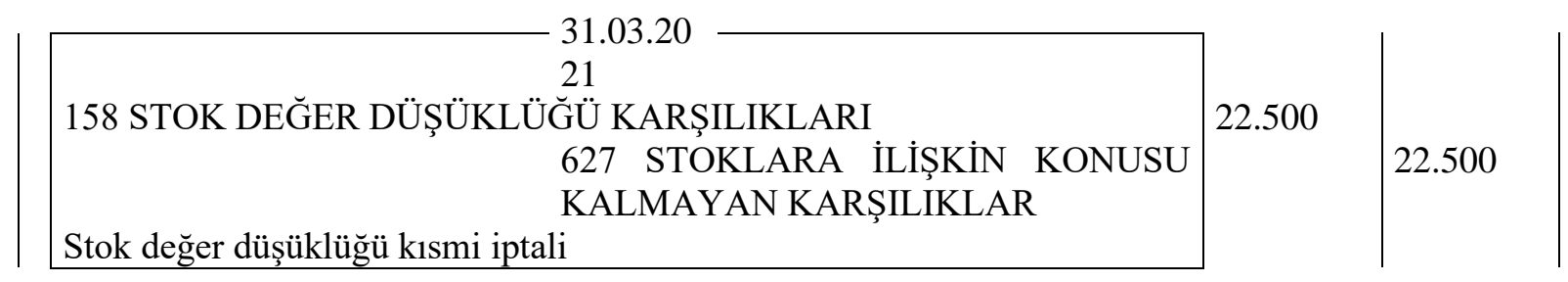

Yapılan bu kayıtla birlikte söz konusu ürünler için ayrılmış olan değer düşüklüğü karşılığg 5.000 TL'ye düşürülmüştür. Bu ürünlerin tamamının 600.000 TL'ye satılmış olması durumunda, satışa ilişkin stoktan düşüm kaydının aşağıdaki gibi yapılması gerekmektedir.

\begin{tabular}{|l|l|l|}
\hline \begin{tabular}{l|l} 
358 STOK DEĞER DÜŞÜKLÜĞÜ KARŞILIKLARI \\
621 SATILAN TİCARİ MALLAR MALIYETİ \\
153 TİCARİ MALLAR
\end{tabular} & 5.000 & \\
Stok değer düşüklüğü kısmi iptali & 570.000 & \\
\end{tabular}

\section{SONUÇ VE ÖNERILER}

Stoklar, tüm işletme türleri açısından son derece önemli bir varlık kalemidir. Stokların ilk muhasebeleştirilmesinden, satışına ve raporlama dönemi sonunda değerlemesine kadar geçen süreçte maliyetlerinin belirlenmesi ve ölçüm esasları açısından yürürlükte olan standart setleri ve VUK'a göre bir takım farklılık ve benzerlikler bulunmaktadır. Söz konusu farklılık ve benzerlikleri aşağıdaki gibi özetlemek mümkündür.

Borçlanma maliyetleri bakımından, TMS ve BOBİ FRS kısmen örtüşmekte, VUK ise standart setlerinden ayrışmaktadır. TMS 2'ye göre vade süresi ne olursa olsun vade farkı finansman maliyeti olarak değerlendirilirken, BOBİ FRS'ye göre 1 yılın altında vade süresi olan alımlardan kaynaklanan vade farklarının maliyete eklenmesi gerekirken, 1 yılın üzerinde olan vadelerde ortaya çıkan vade farklarının finansman maliyeti olarak dikkate alınması gerekmektedir. VUK'a göre ise genel olarak vade farkının maliyete ilave edilmesi gerekmektedir. Ancak, kredi kullanımından kaynaklanan finansman maliyetlerinin varlığın aktife alınmasından sonra ortaya çıkmış olması şartıyla gider olarak kaydına izin verilmektedir.

Standart setlerine göre üretilmesi normal şartlar altında bir yıldan daha uzun süren, özellikli varlık niteliğindeki stokların elde edilmesiyle doğrudan ilişkili borçlanma maliyetleri ise söz konusu stokun satışa veya kullanıma hazır hale geldiği tarihe kadar stok maliyetine dâhil edilirken sonrasında ortaya çıkan borçlanma maliyetlerinin dönem gideri olarak kaydedilmesi gerekmektedir. VUK'ta ise böyle bir ayrım yapılmamıştır.

Standart setlerine göre stok edinimlerinde ortaya çıkan kur farklarının dönem gideri veya geliri olarak kaydedilmesi gerekmektedir. VUK'a göre ise kur farklarının, stokların işletme aktifine dahil edildiği tarihe kadar oluşan kısmının stok maliyetine dahil edilmesi zorunludur. Stokların işletme 
aktifine girmesinden sonra ortaya çıkan kur farklarının ise stok maliyetine dahil edilmesi ya da dönem gideri olarak kaydedilmesi ise işletmelerin tercihine bırakılmıştır.

TMS ve BOBİ FRS ile VUK arasındaki önemli bir diğer farklılık ise mamul maliyetinin kapsamına giren maliyet unsurları bakımından ortaya çıkmaktadır. VUK'a göre mamul maliyeti tam maliyet yöntemine göre belirlenmektedir. TMS 2'ye göre mamul maliyetinin hesaplanmasında normal maliyet yöntemi benimsenmişken, BOBİ FRS'ye göre ise tam maliyet veya normal maliyet yöntemi kullanılabilmektedir. Bu bakımdan VUK'a göre genel üretim giderlerinin tamamı mamul maliyetine dahil edilirken, TMS'ye ve normal maliyet yöntemi tercih edilmesi halinde BOBİ FRS'ye göre genel üretim giderlerinden âtıl kapasiteye isabet eden kısım mamul maliyetine dahil edilmemektedir. Standart setlerine göre stokların bulunduğu konum ve duruma getirilmesinde katkısı bulunmayan genel yönetim giderlerinden mamul maliyetine pay verilmezken VUK'a göre genel yönetim giderlerinden mamul maliyetine pay verilmesi işletmelerin tercihine bırakılmıştır.

Stokların dönem sonu değerlemesi TMS ve BOBİ FRS'ye göre maliyet bedeli ve net gerçekleşebilir değerden düşük olanı üzerinden her raporlama döneminde yapılırken, VUK göre maliyet bedeli üzerinden yapılmaktadır. VUK'a göre değer düşüklügünün varlığı halinde söz konusu değer düşüklüğünün gider olarak kayda alınabilmesi için emsal değer tespitinin yapılmış olması gerekmektedir.

Yukarıda açıklandığı üzere, standartlar ile VUK arasındaki farklılıklara ilişkin işlemlerde, vergi etkisinin bulunması halinde ortaya çıkan farka ilişkin vergi tutarının ertelenmiş vergi varlı̆̆ ya da yükümlülüğü olarak kaydedilmesi de gerekmektedir. $\mathrm{Bu}$ bakımdan VUK ile standartların uyumlaştırılmasına yönelik çalışmaların bu tür karmaşıklıkların ortadan kaldırılması bakımından faydalı olacağı düşünülmektedir.

\section{KAYNAKÇA}

Arısoy, K. ve Tuğay, O. (2019). Stok maliyetlerinin ulusal ve uluslararası mevzuat çerçevesinde incelenmesi ve bir uygulama. Atatürk Üniversitesi İktisadi ve İdari Bilimler Fakültesi Dergisi, 33(1), 155-178.

Demir, E. (2015). Muhasebede iskonto ve komisyon uygulamaları. Üçüncü Sektör Sosyal Ekonomi Dergisi, 50(1), 124-153.

Doğan, A. (2018). Büyük ve orta boy işletmeler için finansal raporlama standardı ile vuk/msugt karş1laştırması. Muhasebe ve Finansman Dergisi, 80, 115-131.

Gençoğlu Gücenme, Ü. (2017). Temel konularda bobi frs ve tms/tfrs karşılaştırması. Muhasebe ve Finansman Dergisi, 76, 1-24. 
Gökçen, G. ve Baysak, İ.A. (2019). Birleşik imalatta ortak ve yan mamullerin maliyetlerinin hesaplanmas1 ve entegre et tesisinde bir uygulama. Ida Academia Muhasebe ve Maliye Dergisi, 2(1), 38-66.

Kamu Gözetimi Muhasebe ve Denetim Standartları Kurumu. Büyük ve Orta Boy İşletmeler İçin Finansal Raporlama Standard1, www.kgk.gov.tr, (Erişim Tarihi: 25.12.2020).

Kamu Gözetimi Muhasebe ve Denetim Standartları Kurumu. Türkiye Muhasebe Standardı 2 Stoklar, www.kgk.gov.tr, (Erişim Tarihi: 23.12.2020).

Kamu Gözetimi Muhasebe ve Denetim Standartları Kurumu. Türkiye Muhasebe Standardı 23 Borçlanma Maliyetleri, www.kgk.gov.tr, (Erişim Tarihi: 26.12.2020).

Karakaya, M. (2007). Maliyet Muhasebesi, Ankara: Gazi Kitabevi.

Katma Değer Vergisi Genel Tebliği No 26, 31.12.1987 Tarih ve 19681 (Mükerrer) Say1lı Resmi Gazete.

Kaya, H.P. (2018). Stoklara İlişkin TMS ve BOBİ FRS Karşılaştırması. Muhasebe Bilim Dünyası Dergisi, 20(2), 262-285.

Kaygusuzoğlu, M. (2010). Vadeli alım-satım işlemlerinin tekdüzen muhasebe sistemi ve muhasebe standartları açısından incelenmesi. Adlyaman Üniversitesi Sosyal Bilimler Enstitüsü Dergisi, 3(5), 184-199.

Kıymetli Şen, İ. ve Özbirecikli, M. (2018). Bobi frs'nin muhasebe uygulamalarına getirdiği değişiklikler: bob frs, tms/tfrs ve mevcut muhasebe sistemi çerçevesinde bir inceleme. Muhasebe ve Vergi Uygulamaları Dergisi, Özel Say1, 462-484.

Özbirecikli, M., Kıymetli Şen, İ. ve Tüm, K. (2017). Uygulamaya Dönük Örnekli Açılamalarla Büyük ve Orta Boy Işsletmeler İçin Finansal Raporlama Standardı. Ankara: Detay Yayıncilik.

Özerhan, Y. ve Sultanoğlu, B. (2018). Msugt-Tms/Tfrs Karşılaştırmalı Uygulamalı Bobi Finansal Raporlama Standardl. Ankara: Gazi Kitabevi.

Özerhan, Y. ve Yanık, S. (2015). IFRS/IAS İle Uyumlu TMS/TFRS Açıklamalı ve Örnek Uygulamalı Türkiye Muhasebe Standartları Türkiye Finansal Raporlama Standartları. Güncelleştirilmiş 3.Baskı, Ankara: Türmob Yayınları.

Öztürk, E. (2017). Stok maliyetlerinin ölçüm ve muhasebeleştirme esaslarının vuk, tms/tfrs ve yfrç taslağı açısından karşılaştııılması. Pamukkale Üniversitesi Sosyal Bilimler Enstitüsü Dergisi, 28, 141-157. 
Özulucan, A. ve Temel, E. (2020). Vergi usul kanunu ve türkiye muhasebe standard1-2 çerçevesinde stokların incelenmesi ve finansal raporlama standartlarına uygun hesap planı taslağı'na göre muhasebe uygulamaları. Muhasebe ve Vergi Uygulamaları Dergisi. 13(3), 911-947.

Selvi, Y. ve Ercan, M. (2018). Bobi frs kapsamında stoklar. Muhasebe Enstitüsü Dergisi, 16(59), 47-57.

Vergi Usul Kanunu. www.gib.gov.tr, (Erişim Tarihi:25.12.2020).

Vergi Usul Kanunu Genel Tebliği, No:238, 02.03 .1995 tarih ve 22218 Say1lı Resmi Gazete.

Yalçın, S. (2019). Türkiye finansal raporlama standartları, büyük ve orta boy işletmeler için finansal raporlama standardı ve muhasebe sistemi uygulama genel tebliğlerinde stoklar: muhasebeleştirme, değerleme, sunum ve açıklamalar. Dumlupınar Üniversitesi Sosyal Bilimler Dergisi, 60, 202-222. 